JARES, Vol. 1 No. 1 March, 2016; p-ISSN: 2502-826X; e-ISSN: 2503-1163

Copyrights@ Balitar Islamic University, Blitar, Indonesia; Http://jares.unisbablitar.ejournal.web.id

Citation: Supriyono. 2016. Developing Character Education with Reference to

Islamic Perspective: A Conceptual Review. JARES, (2016), 1(1): 1-32.

\title{
DEVELOVING CHARACTER EDUCATION WITH REFERENCE TO ISLAMIC PERSPECTIVE: A CONCEPTUAL REVIEW
}

\author{
Supriyono \\ Balitar Islamic University \\ Email: yonsupriyono@gmail.com
}

\begin{abstract}
The paper focuses on the description of how character education is effectively developed and implemented. Using qualitative descriptive method, the writer presents efforts for character education in various countries and synrthesizes to formulate a proposed effective character education system. Character education in Indonesia has been the priority and the implentation is mandated to be included in all subject matters through curriculair and extra-curriculair activities. Effective practical implementation must be taken care off. The suggestive development and implementation of the character education include the strenghtenning of being valued people as in ikhsan, being good creatures of Allah as in Iman, and being able to do good deeds and moral action in the community as in Islam. These can be done through academic lessons, habituations, creativity-action and services. Character development is suggested to be internalized in the wholistic education system by developing the whole students' potential through various active learnings and habituation.
\end{abstract}

Keywords: Character, Character Education, Islamic Perspective

Received: 10 January, 2016; Accepter: 15 March, 2016

\section{INTRODUCTION}

This paper is presented to propose the development and implementation of character education in Indonesia. Character education has been a prominent issues in Indonesia recently. This is partly because in this reformation era, quality of Indonesian citizen must be developed to cope with the rapid demand of Indonesian development and partnerships with other countries. We are now facing the challenging situation where democracy is moving from the representative democracy to participative democracy while globalization penetrates our lives (Supriyono, 2012:2). In this context, the backdrop and the failure of our nation will depend on the quality of our people. Our natural resources are not all of those that can determine the advancement of our nation, but the quality of human resources do (Direktorat Pembinaan Pendidikan Anak Usia Dini, 2012:1). We have big challenges in the context of human resource quality nowadays. The Indonesian human development index has been as 
JARES, Vol. 1 No. 1 March, 2016; p-ISSN: 2502-826X; e-ISSN: 2503-1163

Copyrights@ Balitar Islamic University, Blitar, Indonesia; Http://jares.unisbablitar.ejournal.web.id

Citation: Supriyono. 2016. Developing Character Education with Reference to

Islamic Perspective: A Conceptual Review. JARES, (2016), 1(1): 1-32.

low as the 124 world rank that is bellow average. It has been reported that the 2011 Human Development Index of Indonesia reached 0.617 that was bellow the Medium Human Development of 0.630 and the East Asia and Facific Human Development Index of 0.671 as well as the World Human Development Index of 0.682 (UNDP, 2012). In the Southeast Asia area, we locate ourselves bellow Singapura, Malaysia, Thailand, and the Phillipines. This is not a small chalange. Meanwhile, the preamble of UUD 1945, the Longterms Development Plan (2005-20025), and the Mid-term Development Plan (2010-2014) mandate protection, intelectual development, and prosperity of all Indonesian citizens (Kementrian Pendayagunaan Aparatur Negara dan Birokrasi, 2011:2).

The obvious challenges that we can see in our lives everyday have been the practices of non-good governance in various public services. Public evidences of corruption cases, stealing, robbing, human trafficking, yourster deliquency, community fights, unconstructive demonstration, terorism, and other kinds of crimes show the weaknesses of our human good character. Such actions will be more challenging to manage when Indonesian people cannot cope with the drastic rapid development of technology and capitalistic economic growth. The advance technology, capitalistic economic growth, and cosumerism can be driving forces for those who are materialistic and are weak in good character, values, and norms. In turns, they will disturb our community. One of the examples has been reported by the local newspaper in East Java on September 11, 2012. It was reported that around a thousand of young girls had been involved in human traficking whose organizer named "Keyko" has been caughed by the police in Bali (Surya, September 11, 2012). The modus of traficking has been using smart cellphone and internet banking. Such people have misused of technology and neglected our norms, values, Pancasila, and religion.

In western countries, such as United States, character education has long been important issues since there had been behavioral misconduct such as stated by Whitey (2007:3) as follows:

"Many are witnessing what they believe is an erosion of morals and values among students and feel that this perceived lack of morals and values is contributing to low test scores, poor attendance, lack of discipline, and general lack of respect for authority. With this in mind, many teachers and administrators are now implementing programs in their schools to promote good morals and values that they feel are no longer being taught in the home".

Meanwhile, Davidson, Lickona, and Khmelkov (2007:270) described that the adolescent behavior such as "suicide rates, teen violence, declining academic performance, increasing drug usage, and precocious sexual activity" has been a motivating rationale of the character education. Another reason for the need of character education was stated by Myers (2000), in Vessels and Huitt (2005:3) that the need to educate for character and community has been viewed as critically important by a majority of Americans, ranking ahead of 
JARES, Vol. 1 No. 1 March, 2016; p-ISSN: 2502-826X; e-ISSN: 2503-1163

Copyrights@ Balitar Islamic University, Blitar, Indonesia; Http://jares.unisbablitar.ejournal.web.id

Citation: Supriyono. 2016. Developing Character Education with Reference to

Islamic Perspective: A Conceptual Review. JARES, (2016), 1(1): 1-32.

concerns about academic achievement or other social pressing issues such as racial and gender equality.

For educators and scholars, such situation and issues must be concerned as serious challenge to our young generation education. There must be a more effective way to educate our young generation to be able to perform good behavior reflected from the good character and resulted from values and norms building. Questions must be raised whether character education will only deal with good behavioral development, or also deal with values and norms building in the mind and act of people and whether every person can easily accept character intervention.

Every human being basically has potential for performing good character which suit to the nature of human creation since he/she was being borned (Direktorat Pembinaan Pendidikan Anak Usia Dini, 2012:1). However, there must be a long process of the development of good character through parenting, education, and sosial activities. Families, Schools, and Community play very important roles in forming, developing, and educating human good character. Role model and habit forming in the family lives will be strong ways to develop human good character. Positive and religious sosial activities will also be strong ways to develop human good character. Effective schooling must be a strong way to educate our people to enable them to perform good character. Moreover, a strong and more effective intervention to family and community by higher institution will be much more useful to develop Indonesian people good character.

In fact, character education has been being serious attention to the government and institutions. The National Law of Education number 20, 2003 chapter II verse 3 states that:

"Pendidikan nasional berfungsi mengembangkan kemampuan dan membentuk watak serta peradaban bangsa yang bermartabat dalam rangka mencerdaskan kehidupan bangsa, bertujuan untuk berkembangnya potensi pesertaidik agar menjadi manusia yang beriman dan bertakwa kepada Tuhan Yang Maha Esa, berakhlak mulia, sehat, berilmu, cakap, kreatif, mandiri, dan menjadi warga negara yang demokratis serta bertanggung jawab."

Thus, National education fungtions to develop abilty and to form valued nation character and civilization to smarten the nation lives that is aimed to develop learners potential in order to be Indonesian citizen who are faithful and pious to the God, the Almighty. Furthermore, learners also are expected to be noble, healthy, knowledgeable, competent, creative, independent, democratic, and responsible. In fact, the Indonesian government also has put strong attention on the character education by revealing the national policy for character education.

This paper aims at contributing ideas on the development of good character among students, teachers, lecturers, and other educators. The discussion will include the conception of good character, the national strategies to develop good characters within educational institution, a short look at the character education abroad, roles of family and community in 
JARES, Vol. 1 No. 1 March, 2016; p-ISSN: 2502-826X; e-ISSN: 2503-1163

Copyrights@ Balitar Islamic University, Blitar, Indonesia; Http://jares.unisbablitar.ejournal.web.id

Citation: Supriyono. 2016. Developing Character Education with Reference to

Islamic Perspective: A Conceptual Review. JARES, (2016), 1(1): 1-32.

developing good characters, practices of character development at schools, and proposed ways of developing good character.

This paper used descriptive qualitative approach with aconceptual review by using synthesis analysis design. The procedure of the analysis was synthezing theories, policies, ideas, and practices regarding the character education and formulating suggestive concept of the development and implementation of the character education development. This is a descriptive form of presentation that uses literatures and professional ideas for proposing the alternative ways of developing and implementing character education. The focus will then be how good character education is managed and implemented.

It is expected that this paper will be usefull to scholars, educators, students, parents, regulators, and other parties whon are interested in developing good character education.

\section{CONCEPTION OF GOOD CHARACTER}

Cunningham (2007:1) states that there are three conception of character. The first conception is seeing it as the extent to which a moral agent exemplifies the moral ideas of a society. The second conception is viewing it as the particular set of qualities or traits exhibited by a given person, without regard socially-sanctioned ideals. The third conception is defining character as the complex system of habits that support or impede the development of a person's unique potential for excellence. Thus, we see it in terms of whether a person is actualizing those qualities that have been chosen by that person as worthy or ideal.

These three conception reveals understandings of (1) normative character such as honesty, perseverance, modesty, and temperance converted into behaviors or qualities of agents that conduce to those behaviors (that is, traits), and result an idealized moral agent who seems to embody the ideals, who seems to exhibit ideal moral character; (2) descriptive character, or non-normative character in that everyone has their own unique "character," which is what it is without regard to socially-sanctioned ideals' and (3) personal character in that every individual is reaching his or her own unique potentials for excellence.

Thus, character education can means the development of individual potential in the normative character which deals with value and norms, descriptive character which deals with morality, and personal character which deals with personal quality of performing unique potentials for excellence in behavioral action. In this instance, character means traits, moral, and personal quality. followings:

According to the enclycopedia of Wikipedia (2012) character education defines as the

"Character education is an umbrella term loosely used to describe the teaching of children in a manner that will help them develop variously as moral, civic, good, mannered, behaved, non-bullying, healthy, critical, successful, traditional, compliant and/ or socially-acceptable beings. Concepts that now and in the past have fallen under this term include social and emotional learning, moral reasoning/cognitive development, life skills education, health education, violence prevention, critical 
JARES, Vol. 1 No. 1 March, 2016; p-ISSN: 2502-826X; e-ISSN: 2503-1163

Copyrights@ Balitar Islamic University, Blitar, Indonesia; Http://jares.unisbablitar.ejournal.web.id

Citation: Supriyono. 2016. Developing Character Education with Reference to

Islamic Perspective: A Conceptual Review. JARES, (2016), 1(1): 1-32.

thinking, ethical reasoning, and conflict resolution and mediation. Many of these are now considered failed programs i.e., "religious education", "moral education", "values clarification"

This definition focuses on the teaching of children, meanwhile character development will not only deal with children, but young adult and teenagers. In this case, character is perceived as:

"...one of those overarching concepts that is the subject of disciplines from philosophy to theology, from psychology to sociology - with many competing and conflicting theories. Character as it relates to character education is most often used to refer to how 'good' a person is - in other words, a person who exhibits personal qualities which fit with those considered desirable by a society might be considered to have good character and developing such personal qualities is often then seen as a purpose of education. However, the various proponents of character education are far from agreement as to what "good" is or what qualities are desirable to develop" (Wikipedia, 2012).

Nelson, Nelson, and Christoper (2003:82) said that character education deals with the cultivation of values and virtue. Therefore, it is believed that it should be of vital interest to all members of society including scholars and educators. In this case, character means the personal quality of the universal values. They further said that:

Character education attempts to shape the moral visions within which the next generation become socialized and enculturated. By moral visions, we are reffering to collective understanding of what the self is and how the self to be in the world.

Thus, character is perceived as moral quality of an individual that will formulate the character of society.

Salahudin, P.Z. (2011:5-8) identified that character education can be viewed from several theories. The first theory is the cognitive development that reveals developmental approach. It theorizes that children develop morally in stages. This theory appears to be developed by Lawrence Kohlberg and similar theory also was developed by Jean Piaget. This theory associates character development with moral judgment and places a child's moral growth into developmental stages. The second theory is based on the psychological persepective that reveals psychological approach to character development. It associates character development with virtues. In this case Salahudin, P.Z. (2011:5) said that:

"The psychological perspective espoused by Lickona (1991) suggests that children can be taught character by teaching them virtues such as honesty and respect. Literature representing the psychological theory argues that virtues such as respect, 
JARES, Vol. 1 No. 1 March, 2016; p-ISSN: 2502-826X; e-ISSN: 2503-1163

Copyrights@ Balitar Islamic University, Blitar, Indonesia; Http://jares.unisbablitar.ejournal.web.id

Citation: Supriyono. 2016. Developing Character Education with Reference to

Islamic Perspective: A Conceptual Review. JARES, (2016), 1(1): 1-32.

responsibility, and honesty are primary elements for character development (Character

Education Partnership, 2006)".

The other theory is the social learning theory that suggests that a child's environment plays a vital role in forming the child's character. This theory is presented by Wynne (1997). Salahudin, P.Z. (201:5) described that:

"According to Wynne, environments include activities and opportunities intended to develop and foster character education. At some point in the discourse, these theories of cognitive, psychological and social learning, embrace virtues in some aspect. It is from these three theoretical frameworks that this discussion of character education ensued"

Thus, character and character education deals with morality, virtue, and environment. In another perspective, Bajovic, M., Rizzo, K., and Engemann, J. (2009:3) formulated that

“...character is considered as a sociomoral competency that incorporates moral action, moral values, moral personality, moral emotions, moral reasoning, moral identity, and foundational characteristics. Character also must be comprehensively defined to include thinking, feeling, and behavior, and character should be accepted as a family of positive traits reflected in those thoughts, feelings, and behaviors.

Hunter (2000), in Bajovic, M., Rizzo, K., and Engemann, J. (2009:4) defines character as the amalgamation of three elements: moral discipline, moral attachment, and moral autonomy. In this case, character is proposed to be constructed with those moral elements. It is influenced by both the individual differences in knowing and understanding of moral norms and with different social and cultural factors that determine individuals' moral behaviour. Therefore, character deals with morality and a good character person will know the good, desire the good, and do the good.

Huitt, W.G.,P.hd.(2000:4) states that character is the moral quality and direction of one's decisions and behavior. This definition has similarity with the previous definitions discussed afforementioned. Huitt also cited two definitions that related to the normative views stated by Wynne, E., and Walberg, H. and Pritchard.

Wynne, E., and Walberg, H. (1984), in Huitt, W.G., P.hd.(2004:5) state that character is... "engaging in morally relevant conduct or words, or refraining from certain conduct or words" . Meanwhile, Pritchard, I (1988), in Huitt, W.G.,P.hd (2004:6) states that character is..." a complex set of relatively persistent qualities of the individual person, and generally has a positive connotation when used in discussions of moral education" Thus, according to the normative view, character is dealing with morality in words and action.

Gholar, C. (2004) defines character education in several definitions that can be stated as the followings:Firstly, character education is the term used to describe many aspects of teaching and learning for personal development. Secondly, character education is an approach that connects the morality of education to the social and civic aspects of students' everyday lives. Thirdly, some terms that fall under the "umbrella" of character education and 
JARES, Vol. 1 No. 1 March, 2016; p-ISSN: 2502-826X; e-ISSN: 2503-1163

Copyrights@ Balitar Islamic University, Blitar, Indonesia; Http://jares.unisbablitar.ejournal.web.id

Citation: Supriyono. 2016. Developing Character Education with Reference to

Islamic Perspective: A Conceptual Review. JARES, (2016), 1(1): 1-32.

are taught as part of a program include: moral reasoning, social and emotional learning, moral education, life skills education, caring community, health education, violence prevention, conflict resolution and peer mediation and ethics. Fourthly, character education may also be defined as the development of knowledge, skills and abilities that enable one to make informed and responsible choices while coming face to face with the realities of life. It emphasizes responsibility and rewards participants who live productively in the diverse world.

Character is then related with morality, social and civic aspects of lives, ethics, life skills, and personal responsibilities in lives. Lickona, T., E, Scaps, E, and Lewis, C. (2007:36) said that

"Character education holds that widely shared, pivotally important, core ethical values_-such as caring, honesty, fairness, responsibility, and respect for self and others-along with supportive performance values-such as diligence, a strong worth ethic, and perseverance-form the basis of good character. A school committed to character development stands for these values (sometimes referred to as "virtues" or "character traits"), defines them in terms of behaviors that can be observed in the life of the school, models these values, studies and discusses them, uses them as the basis of human relations in the school, celebrates their manifestations in the school and community, and holds all school membersaccountable to standards of conduct consistent with the core values...Students learn to care about core values by developing empathy skills, forming caring relationships, helping to create community, hearing illustrative and inspirational stories, and reflecting on life experiences. And they learn to act upon core values by developing prosocial behaviors (e.g., communicating feelings, active listening, helping skills) and by repeatedly practicing these behaviors, especially in the context of relationships (e.g., through cross-age tutoring, mediating conflicts, school and community service). As children grow in character, they develop an increasingly refined understanding of the core values, a deeper commitment to living according to those values, and a stronger capacity and tendency to behave in accordance with them.

This means that character deals with ethical values, virtues, character traits, and prosocial behavior. From the above discussion we can understand that character relates with traits, norms, virtues, values, social life skill, and personal quality for socially competent in daily lives. Character education is an effort for building and developing these good characters elements in everybody in order to be able to know, feel, undestand, and conduct good characters in daily social lives. In the context of the Indonesian Nasional Education, character education means educating values, ethical conduct of life, morality, and traits that is aimed at developing ability as citizens to decide good or bad, to correctly behave in social lives, maintain, and to perform good behavior in daily lives (Kementrian Pendidikan Nasional, 2011:5). 
JARES, Vol. 1 No. 1 March, 2016; p-ISSN: 2502-826X; e-ISSN: 2503-1163

Copyrights@ Balitar Islamic University, Blitar, Indonesia; Http://jares.unisbablitar.ejournal.web.id

Citation: Supriyono. 2016. Developing Character Education with Reference to

Islamic Perspective: A Conceptual Review. JARES, (2016), 1(1): 1-32.

The importance of character education in Indonesia is based on the reality that we face a national challenges on the disorientation of and the lack of the internalization of Pancasila values, the limitation of integrated policy to perform Pancasila values, the trend of moving the ethical act on being the citizens in all sorts of lives, the decrease of the awareness toward the nation values and norms, the challenges on the nation disintegration, and the weaknesses of Nation independent (Buku Induk Kebijakan Nasional Pembangunan Karakter Bangsa 20102025).

Character education does not only merely teach right or wrong, but more than this is internalizing habits (habituation) about which are good. Learners will then know and understand good values or right things (cognitive), be able to feel values and norms (Affective), and be able to conduct good behavior (Psychomotor). Character education involves moral knowing, moral feeling, and moral action.

So, character means values and norms that suit with the national values and norms which are based on the National Philosophy of Pancasila. Norms and Values of Pancasila that becomes the National characters are: Believe in the Supreme God, Just and Ethical Humanism, Nationalism, Representation for national decision, and Social justice for overall Indonesian citizen. Therefore, Indonesian people are faithful, respect others in diversity of faithfulness, and respect religious practices other than what being believed. Indonesian people are those who are just, fair, and humanistic. Indonesian people are those who place the national interest above all personal interest. Indonesian people are those who respect diversity and are able to unite in diversity. Indonesian people are those who are able to make shared decision with representation. Indonesian people are those who are socially just and respect for the efforts for peace and prosperity (BP7 Pusat, 1993). It is of course a surprise when we witness evidences of human trafficking, corruption, and other kinds of misconduct behavior.

In the Islamic perspective, character shall be one of the personal quality for the surender to Allah the Almighty, obey Allah and Rasullullah, and doing deeds for the implementation of surrending to the Islam as rahmatan lil alamin. The core guidance for this shall be the so-called "atiullah" and "atiurasul" which are the Qur'an and the Sunnah. To do this Allah has create human beings in the good manners (moulds) as revealed in the Qur'an in Surah At-Tin as follows:

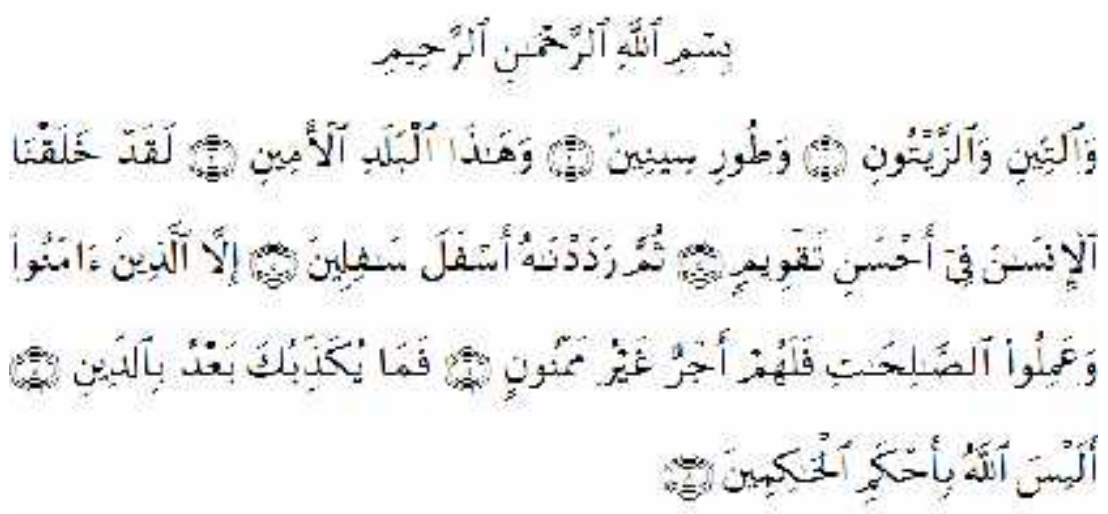


JARES, Vol. 1 No. 1 March, 2016; p-ISSN: 2502-826X; e-ISSN: 2503-1163

Copyrights@ Balitar Islamic University, Blitar, Indonesia; Http://jares.unisbablitar.ejournal.web.id

Citation: Supriyono. 2016. Developing Character Education with Reference to

Islamic Perspective: A Conceptual Review. JARES, (2016), 1(1): 1-32.

In The Name of Allah, Most Gracious, Most Merciful; "By the Fig And the Olive,And the Mount Of Sinai, And this City Of Security, We have indeed created human being In the best of moulds, Then do We abase him/her (To be) the lowest Of the low, Except such believe And do righteous deeds; For they shall have A reward unfailing; Then what can, Afer this, contradict thee. As to the Judgement (To come)?; Is not Allah The wisest Judges?" (QS At-Tin (95):1-8)

In order that the human being are able to having good character Allah provide them with the soul of good and bad by which only those who purify will safe. Allah revealed as follows:

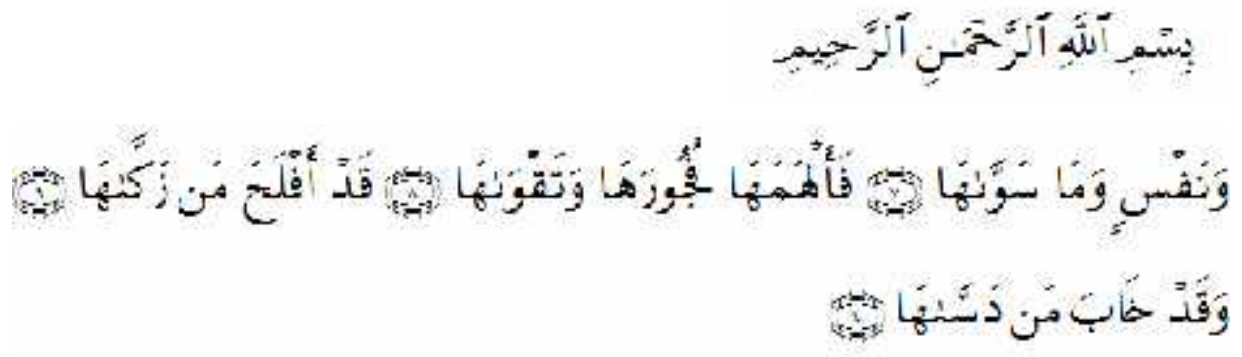

In The Name of Allah, Most Gracious, Most Merciful

"...By the Soul, And the proportion and order Given to it; And its enlightment As to its wrong And its right-Truely he suceeds That purifies it; And he fails That corrupts ir." (QS AsShams (91):7-10)

To make human beings easy to understand good deeds and wrong doing as guided in the Qur'an, Allah gives them other reference of learning which is the Sunnah. Allah revealed:

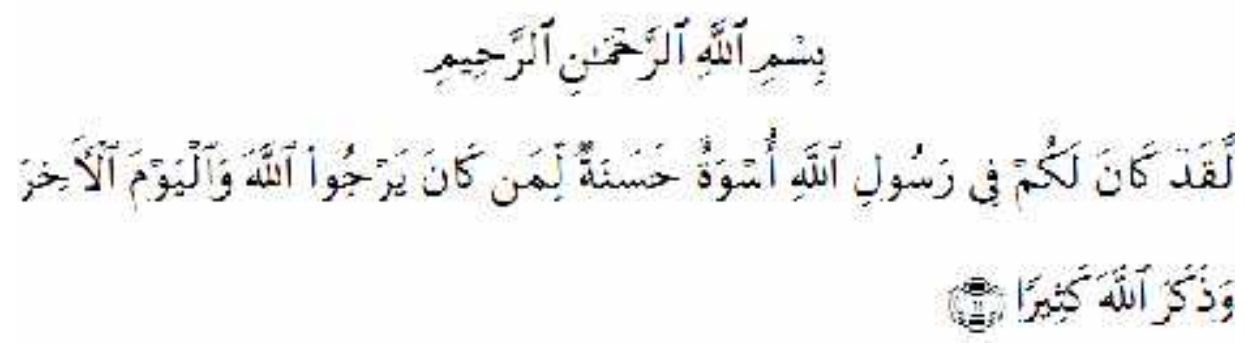

In The Name of Allah, Most Gracious, Most Merciful,"Ye have indeed in the Messanger of Allah a beautiful patern (of conduct) for any one whose hope is in Allah and the Final Day and Who engages much in the Praise of Allah." (QS Al Ahzab (33):21). 
JARES, Vol. 1 No. 1 March, 2016; p-ISSN: 2502-826X; e-ISSN: 2503-1163

Copyrights@ Balitar Islamic University, Blitar, Indonesia; Http://jares.unisbablitar.ejournal.web.id

Citation: Supriyono. 2016. Developing Character Education with Reference to

Islamic Perspective: A Conceptual Review. JARES, (2016), 1(1): 1-32.

There have been lots of good character exemplified by Rasulullah. The big four among thousands of good character of Rasulullah are Fatonah, Amanah, Sidiq, and Tabligh. These four traits of character can be the roots for our character. The Fatonah (Honest), Amanah (Trustworthy), Sidiq (Smart), and Tabligh (Prudent and Communicative). No human beings in this world will do misconduct behavior if they posess and do these four traits of character.

Rasulullah is not only the greatest messanger, but he has been the greatest leaders who has wholistic leadership and management spectrum. His core leadership and religious spectrum is Religious Sipirituality that flourizes on his ability to lead and manage lives in terms of self development, military, legal system, education, social and politics, dakwah, family, and business (Antonio, 2007:13). The norms, values, and social acts are the noble ways that universally can be followed by every people in the world. Rasullullah does not only leave exemplary conduct, but also inspiration and wisdom in all aspects of human lives.

Therefore, the notion of character in the Islamic perspective shall be much better adopted in the effort to educate our nation generation to have good character. All mentioned character definitions that include the character of Pancasila have belong to the notion of character in Islam.

\section{NATIONAL STRATEGIES TO DEVELOP GOOD CHARACTERS}

Considering the decrease of National value conduct and looking at the National strategies to develop good citizen with the good character, we can understand that the policy makers of this country pay much attention on the rise of good Indonesian people. The following is the brief description of the National Strategies to develop good characters.

As aforementioned, the essence of the character education in Indonesia is to develop and to habituate the moral values and norms of Pancasila in our daily lives in order to have peaceful and good lives. The aims of character education is to develop nation character in order that Indonesian people are able to perform the Pancasila values. The character education functions as (1) developing basic potential of people in order to be good hearted, to have good thinking, and to perform good behavior; (2) strengthening and developing multucultural behavior, and to enhance the nation cultural lives which are competitive in the world living relationship. This is done through various media that include family, schools, civil community, political community, government, businesses, and newspapers.

There have been 20 values as the traits to formulate character as seen in Table 1 . These 20 traits include: 
JARES, Vol. 1 No. 1 March, 2016; p-ISSN: 2502-826X; e-ISSN: 2503-1163

Copyrights@ Balitar Islamic University, Blitar, Indonesia; Http://jares.unisbablitar.ejournal.web.id

Citation: Supriyono. 2016. Developing Character Education with Reference to

Islamic Perspective: A Conceptual Review. JARES, (2016), 1(1): 1-32.

Table 1 . The 20 traits and chacarters

\begin{tabular}{|c|c|}
\hline KARAKTER & CHARACTERS \\
\hline $\begin{array}{l}\text { 1. Religius } \\
\text { 2. Percaya diri } \\
\text { 3. Patuh pada aturan-aturan sosial } \\
\text { 4. Menghargai keberagaman } \\
\text { 5. Berpikir logis, kritis, kreatif, dan } \\
\text { inovatif } \\
\text { 6. Mandiri } \\
\text { 7. Nasionalis } \\
\text { 8. Menghargai karya dan prestasi } \\
\text { orang lain } \\
\text { 9. Bertanggung jawab } \\
\text { 10. Bergaya hidup sehat } \\
\text { 11. Santun } \\
\text { 12. Sadar akan hak dan kewajiban diri } \\
\text { dan orang lain } \\
\text { 13. Jujur } \\
\text { 14. Disiplin } \\
\text { 15. Kerja keras } \\
\text { 16. Demokratis } \\
\text { 17. Peduli sosial dan lingkungan } \\
\text { 18. Ingin tahu } \\
\text { 19. Cinta ilmu } \\
\text { 20. Berjiwa wirausaha }\end{array}$ & $\begin{array}{l}\text { 1. Religious/religiosity } \\
\text { 2. Confident/confidence } \\
\text { 3. Complying social rules/social } \\
\text { compliance } \\
\text { 4. Appreciating diversity/appreciation } \\
\text { of diversity } \\
\text { 5. Thinking logically, critically, } \\
\text { creatively, and innovatively } \\
\text { 6. Autonomous/autonomy } \\
\text { 7. Patriotic/patriotism/national pride } \\
\text { 8. Appreciative of works and } \\
\text { achievements of } \\
\text { others/appreciation of achievement } \\
\text { 9. Responsible/responsibility } \\
\text { 10. Having healthy lifestyle/healthy } \\
\text { lifestyle } \\
\text { 11. Courteous/courtesy } \\
\text { 12. Aware of rights and obligations of } \\
\text { self and others/awareness of right } \\
\text { and responsibility } \\
\text { 13. Honest/honesty } \\
\text { 14. Disciplined/discipline } \\
\text { 15. Industrious /industriousness } \\
\text { 16. Democratic/democracy } \\
\text { 17. Caring about social matters and } \\
\text { environment/social and } \\
\text { environmental care } \\
\text { 18. Curious/curiosity } \\
\text { 19. Passionate about learning/passion } \\
\text { for learning } \\
\text { 20. Having entrepreneurial } \\
\text { spirit/entrepreneurship }\end{array}$ \\
\hline
\end{tabular}

Table 1: 20 traits (after Tim Pendidikan Karakter, Kementrian Pendidikan Nasional, 2011)

Looking at these traits, we can understand that these are all included in the Pedoman Penghayatan dan Pengamalan Pancasila (The Guidance of Knowing and Implementing 
JARES, Vol. 1 No. 1 March, 2016; p-ISSN: 2502-826X; e-ISSN: 2503-1163

Copyrights@ Balitar Islamic University, Blitar, Indonesia; Http://jares.unisbablitar.ejournal.web.id

Citation: Supriyono. 2016. Developing Character Education with Reference to

Islamic Perspective: A Conceptual Review. JARES, (2016), 1(1): 1-32.

Pancasila). When we look at the Qur'an and As-Sunnah, these 20 traits are parts of the moslem character mandated by Allah and Rasulullah to conduct. Thus, when we succeeded to educate people about Pancasila and when we succeeded to educate people obey Allah and Rasulullah in the religion of Allah, that is Islam (surender) correctly and thruthfully, we will have good character citizen automatically.

The grand design of the National character education can be figured as follows:

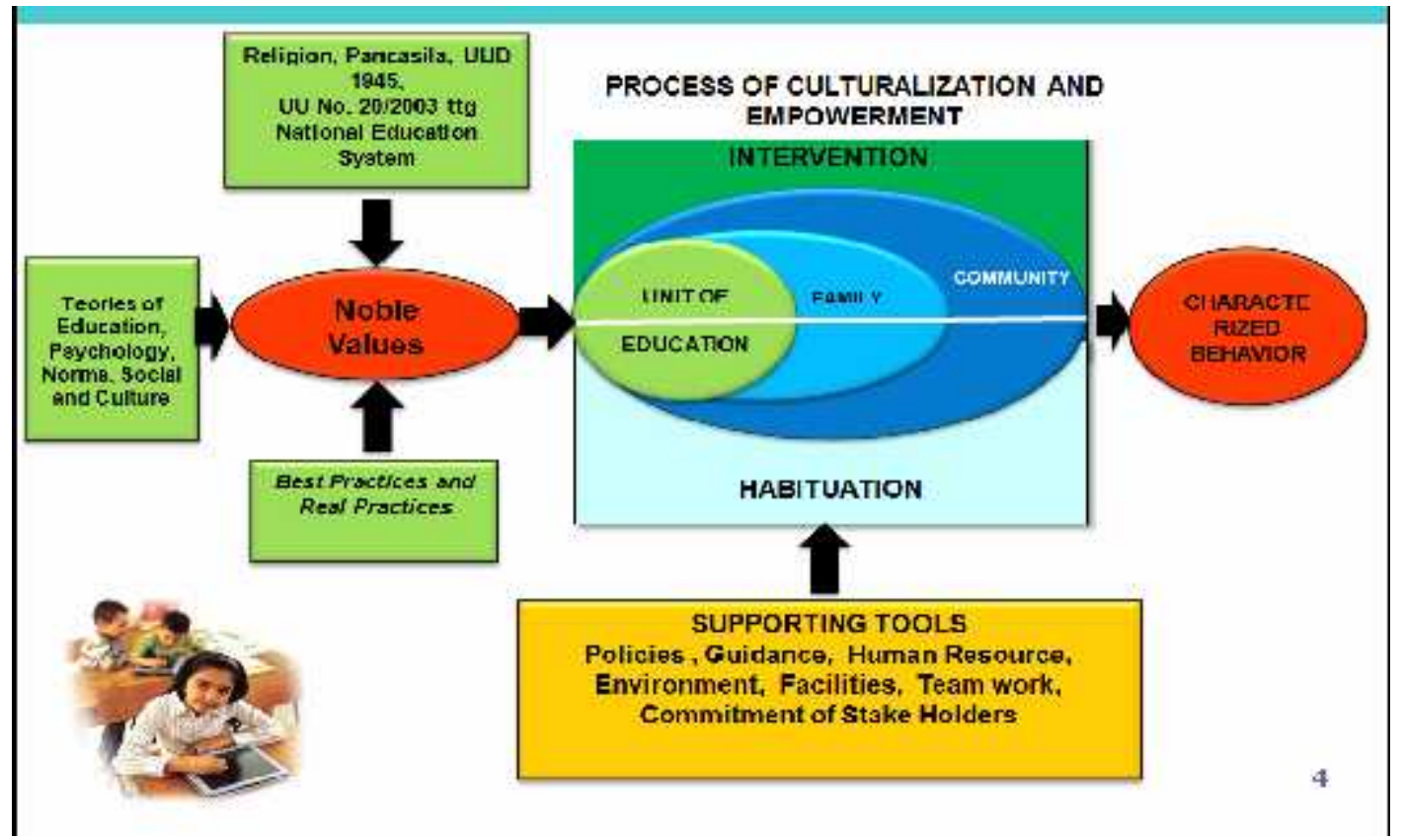

Figure 1: Grand Design of National Character Education (Kementrian Pendidikan Nasional, 2011)

The process of the National Character Education is based on the psychological totality that covers all aspets of human potential including cognitive potential, psychomotoric potential, and affective potential and the sociocultural funtional totality in the context of family, schools, and community (Kementrian Pendidikan Nasional, 2011). This totality can be defined in Figure 2.

Thus, the configuration of the psychological and sociocultural totality of character education can be grouped into the hearted process or the spiritual and emotional development, the thinking process or intelectual development, the physical process or physical and kinesthetic development, and the feeling and willingness process or affective and creativity development. 
JARES, Vol. 1 No. 1 March, 2016; p-ISSN: 2502-826X; e-ISSN: 2503-1163

Copyrights@ Balitar Islamic University, Blitar, Indonesia; Http://jares.unisbablitar.ejournal.web.id

Citation: Supriyono. 2016. Developing Character Education with Reference to

Islamic Perspective: A Conceptual Review. JARES, (2016), 1(1): 1-32.

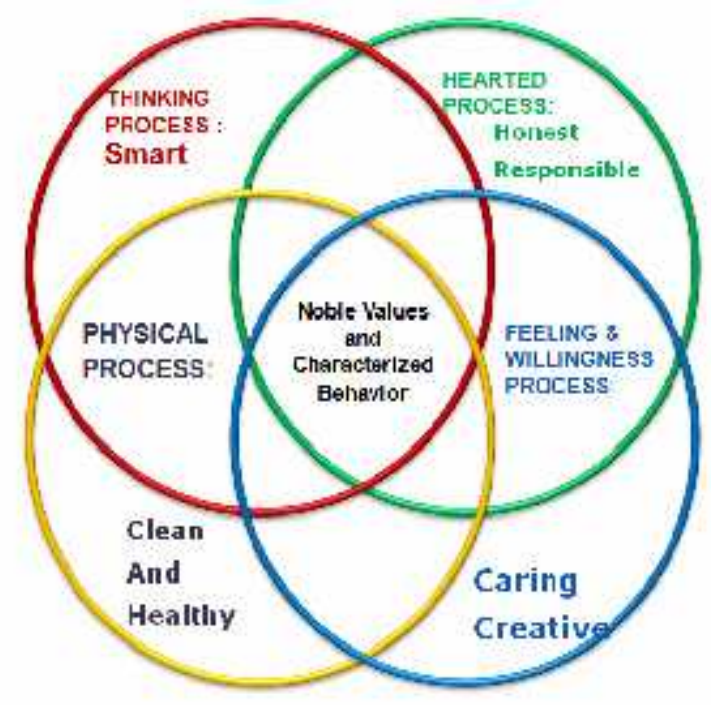

Figure 2: Scope of National Character Education (Mendiknas, 2011).

The strategies of the National Character Education covers strategies at the level of the Ministry of Education, strategies at the regional level, and strategies at the education unit level. At the National level, the character education strategies covers policy intervention (top down stream), unit of education experience (bottom up stream), and program revitalization. These can be shown in figure 3 .

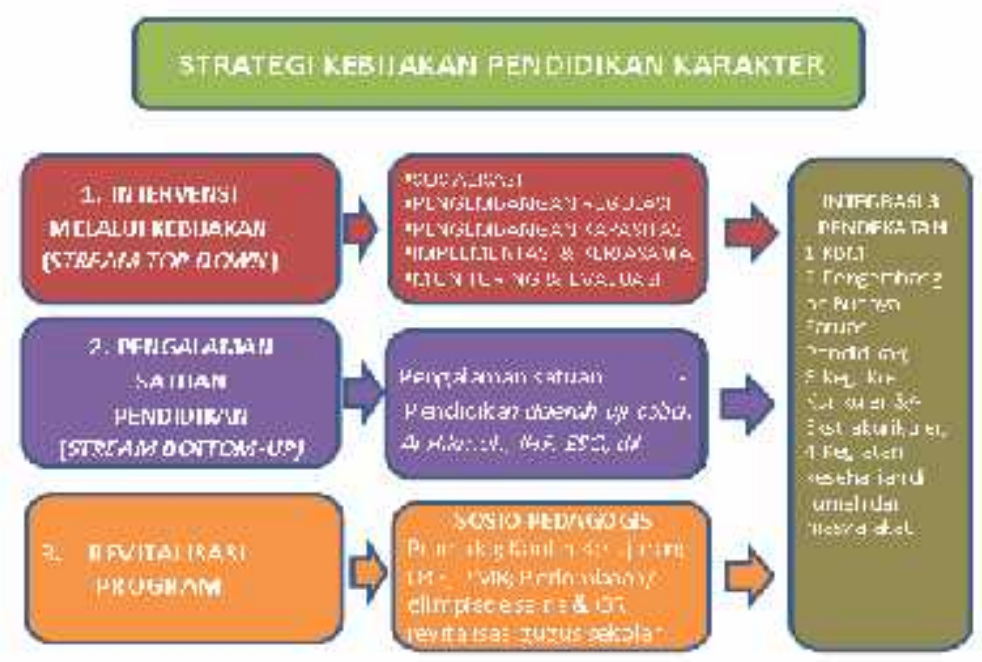

Figure 3: Policy Strategy of Character Education (Kementrian Pendidikan Nasional, 2011) 
JARES, Vol. 1 No. 1 March, 2016; p-ISSN: 2502-826X; e-ISSN: 2503-1163

Copyrights@ Balitar Islamic University, Blitar, Indonesia; Http://jares.unisbablitar.ejournal.web.id

Citation: Supriyono. 2016. Developing Character Education with Reference to

Islamic Perspective: A Conceptual Review. JARES, (2016), 1(1): 1-32.

At the regional level, the policy for the characer education implementation covers construction of policies at the level of municipal and region, preparation and distribution of the prioritized character education materials, supports of the curriculum development team at the level of municipality or district, supports of facilities and budget. At the Unit of Education, the character education strategies can be shown in the figure 4 .

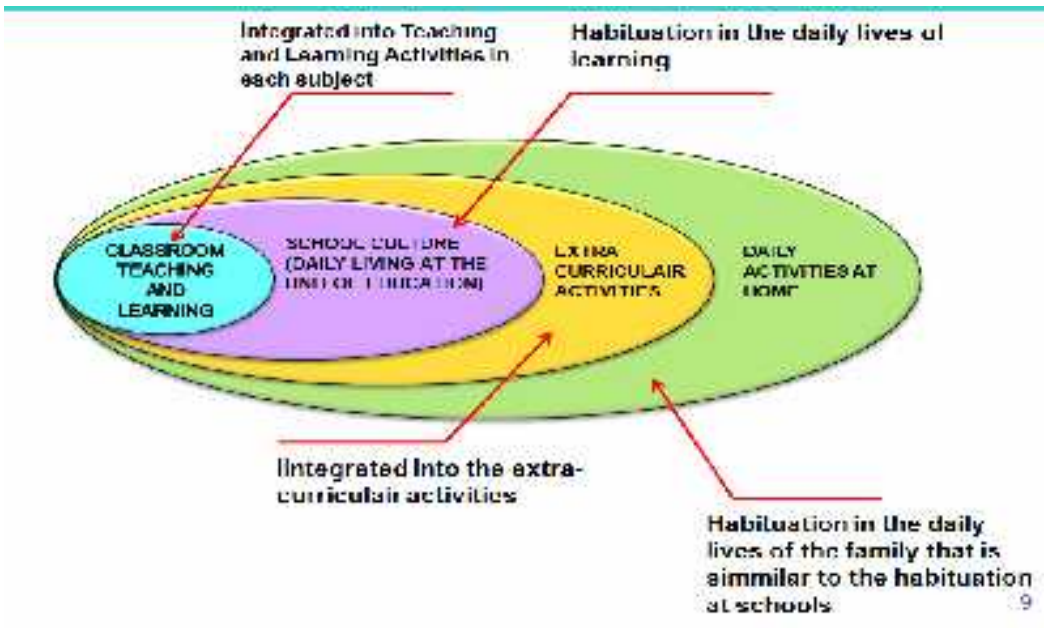

Figure 4: Micro Strategy of Character Education at the School Level (Kementrian Pendidikan Nasional, 2011).

This strategy involves three streams of character development as in figure 5.

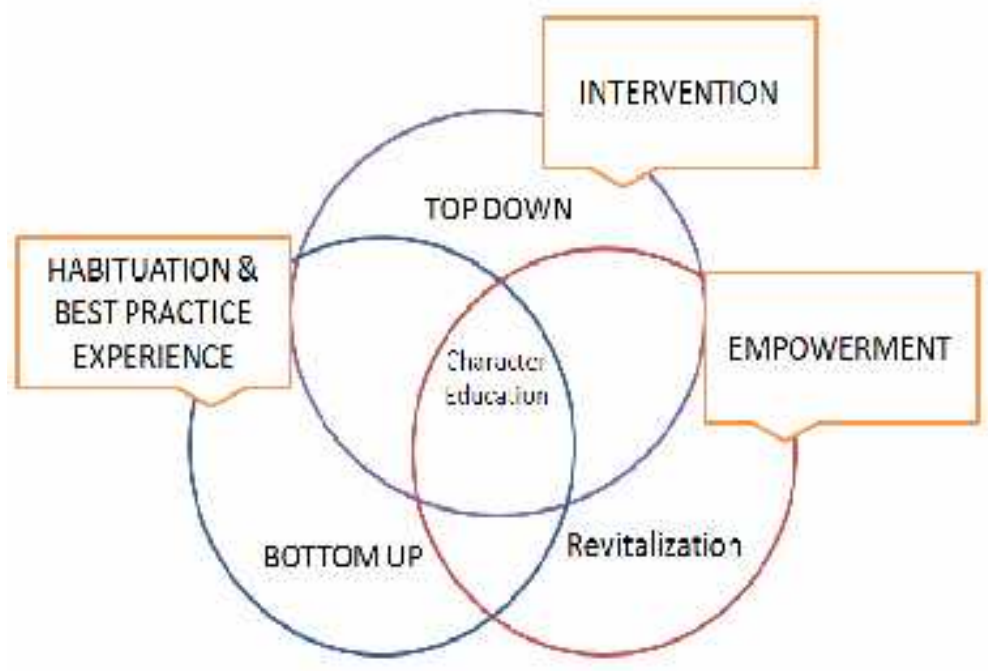

Figure 5: Character Education Streams 
JARES, Vol. 1 No. 1 March, 2016; p-ISSN: 2502-826X; e-ISSN: 2503-1163

Copyrights@ Balitar Islamic University, Blitar, Indonesia; Http://jares.unisbablitar.ejournal.web.id

Citation: Supriyono. 2016. Developing Character Education with Reference to

Islamic Perspective: A Conceptual Review. JARES, (2016), 1(1): 1-32.

\section{A BRIEF REVIEW OF CHARACTER EDUCATION ABROAD}

In Canada, character education is considered very important. Bajovic, M., Rizzo, K., and Engemann, J. (2009:1) describes that:

"In October 2006, The Ontario Ministry of Education introduced Finding Common Ground: Character Development in Ontario Schools K-12, a discussion paper designed to guide the implementation of character education in K-12 public schools within the province. The initiative that spawned this paper requires a commitment from all stakeholders in the school and greater community to engage students in developing positive habits and characteristics of a responsible citizenship. The key beliefs and principles in Finding Common Ground: Character Development in Ontario Schools $K-12$, hold that the values and attributes of character development are "universal and transcend racial, religious, ethno-cultural, linguistic, and other demographic factors". It also states that there is a growing need to find "common ground"”.

This shows the importance of character education in Ontario to develop positive habits and characteristics of a responsible citizenship.

In the United States of America, schooling was formed for the purpose of teaching morals and good character to children (McClellan, 1999). Salahudin, P.Z. (2011) said that:

"Over the years, American educators shifted away from a moral focus in education to an academic focus. However, violent crimes in American schools and a seeming deterioration in moral behavior have parents and educators once again turning their attention to students' character development".

The character education, in the United States of America, began in 17th century. Historically, it was revealed on the basis of the social, political, and economic conditions of the nation that have determined the degree of interest placed on character education (Salahudin, P.Z., 2011:16). Aftewords, there came some of the early settlers seeking religious freedom. Further Salahudin, P.Z. (2011:7) said that:

"Groups such as the Puritans came to America to escape religious persecution in England. Although education was important to the early Americans, their purpose was strictly for developing a child's morals by learning the religion. For 143 years from 1607 to 1750, religious groups in America including the Puritans, Protestants, and Catholics shared similar approaches to the task of developing a child's moral character. They expected the family to take the primary responsibility for educating the child with moral values, with apprenticeship, schooling, and the church serving as important supplementary institutions" 
JARES, Vol. 1 No. 1 March, 2016; p-ISSN: 2502-826X; e-ISSN: 2503-1163

Copyrights@ Balitar Islamic University, Blitar, Indonesia; Http://jares.unisbablitar.ejournal.web.id

Citation: Supriyono. 2016. Developing Character Education with Reference to

Islamic Perspective: A Conceptual Review. JARES, (2016), 1(1): 1-32.

Nowadays, the character education has been flowerized in the United States. It does not only taught in the public and chatolic or christianity schools, but also in the islamic schools. Nelson, Nelson, and Christoper (2003:81) said that character education is rapidlygrowing and heatedly debated movement in the fields of education, religion, and politics stated that the new character education moved from restoring good character to the desirable outcomes of the schools' moral enterprise. The most prominent program established in the Unite States has been the "character count" that promotes the development of good charcters of six pillars. It was established in 1990 by the Josephs and Edna Josephson Institute of Ethics. The six pillars are trustworthiness, respect, responsibility, fairness, caring, and citizenship. With Character Counts program, the United States of America also developed the National Standards for Family-School Partnerships and Character Counts.

Another prominent character education program has been offered by Character Partnership Program (CEP). The CEP formulates eleven principles of character education that consist of (1) promoting core ethical value and supportive performance values as the foundations of good character, (2) defining "character" comprehensively that include thinking, feeling, and behavior, (3) using comprehensive intentional andproactive approach to character development, (4) creating a caring school community, (5) provides students with opportunities for moral action, (6) including a meningful and challenging academic curriculum that respect all learners, develops their character, and helps them to succeed, (7) striving to forster students' self motivation, (8) Engange the school staffs as learning and moral community that shares responsibility for character education and attemps to adhere to the same core values that guide the education of students, (9) fostering shared moral leadership and long range support of the moral education initiative, (10) engaging family and community members as partners in the character building efforts, (11) assessing the character of schools, the schools' staffs functioning as character educators, and the extent to which students manifest good character (Lickona, T., Schaps, E., and Lewis, C., 2007).

In Australia, character education is developed using the National Frame-work for Values Education in Australian Schools. There are three basic conceptions introduced in this framework. These are values for Australian Schooling, Guiding Principles, and Key Elements and Approaches that inform good practice. The values of Australian Schooling contain 9 (nine) values as the followings: (1) care and compassion (Care for self and others), (2) doing your best (Seek to accomplish something worthy and admirable, try hard, pursue excellence), (3) fair go (Pursue and protect the common good where all people are treated fairly for a just society, (4) freedom (Enjoy all the rights and privileges of Australian citizenship free from unnecessary interference or control, and stand up for the rights of others), (5) honesty and Trustworthiness (Be honest, sincere and seek the truth), (6) integrity (Act in accordance with principles of moral and ethical conduct, ensure consistency between words and deeds), (7) respect (Treat others with consideration and regard, respect another person's point of view), (8) responsibility ( Be accountable for one's own actions, resolve differences in constructive, non-violent and peaceful ways, contribute to society and to civic life, take care of the 
JARES, Vol. 1 No. 1 March, 2016; p-ISSN: 2502-826X; e-ISSN: 2503-1163

Copyrights@ Balitar Islamic University, Blitar, Indonesia; Http://jares.unisbablitar.ejournal.web.id

Citation: Supriyono. 2016. Developing Character Education with Reference to

Islamic Perspective: A Conceptual Review. JARES, (2016), 1(1): 1-32.

environment), (9) understanding, tolerance and inclusion (Be aware of others and their cultures, accept diversity within a democratic society, being included and including others).

The guiding principles consist of 8 (eight) points which are:

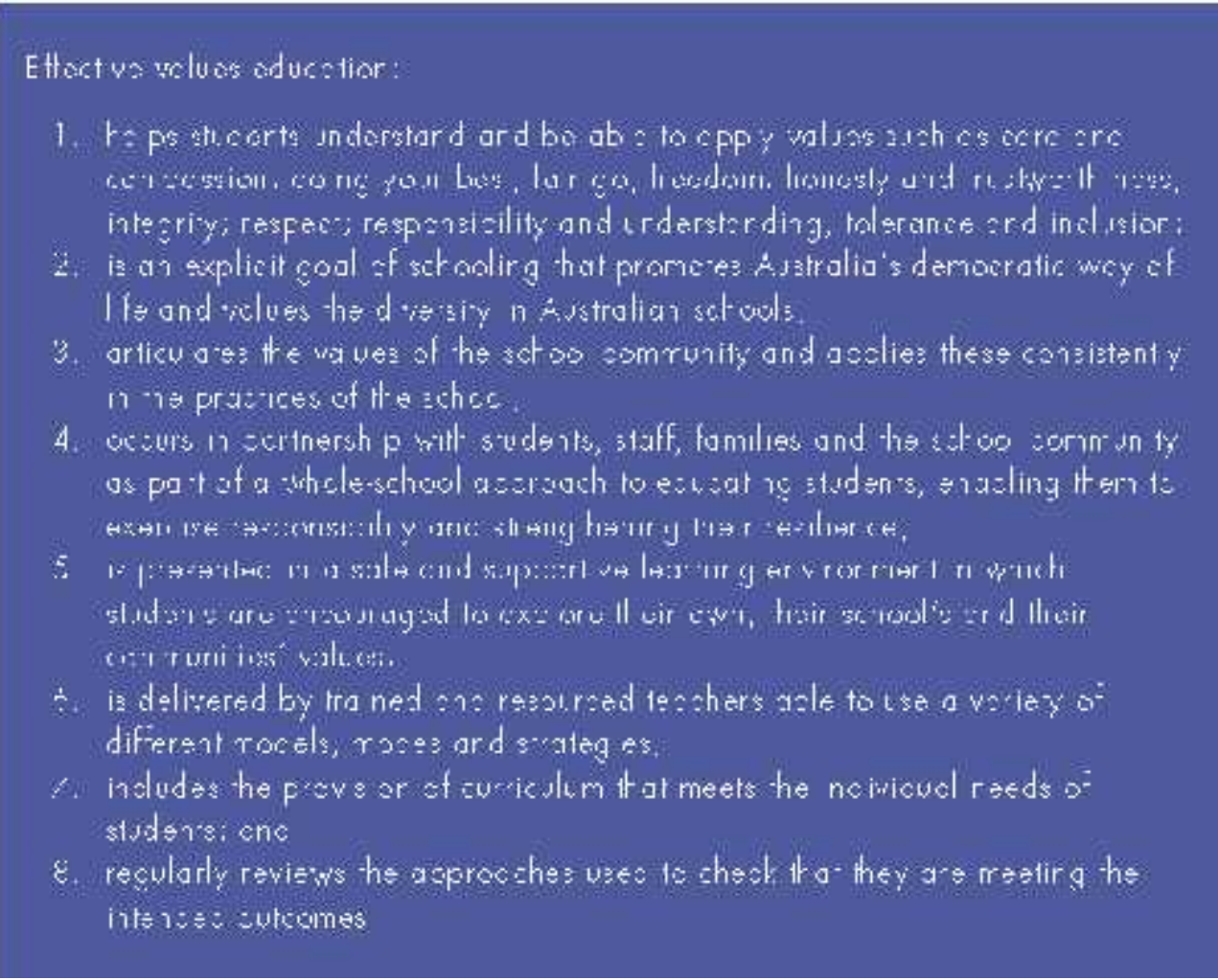

Figure 6: Australian Character Education Guiding Principles (Australian

Government, Department of Education, Science, and Training, 2005)

The Key Elements and Approaches are outlined to guide to implement the character education on the basis of each value with exemplified approaches. With these ideas, it can be said that the Australian Government pays attention on the development of Australian character.

In New Zealand, character education is using the cornerstone values approach to character education. The Cornerstone Values approach to character education was developed by John Heenan, a former school principal and published by the New Zealand Foundation for Character Education Inc ( New Zealand Foundation for Character Education Inc, 2009).

The eight cornerstone values are consistent, constant and transcultural and have been held in common by all cultures and civilizations throughout history. They are:

- Respect

- Responsibility

- Honesty and truthfulness 
JARES, Vol. 1 No. 1 March, 2016; p-ISSN: 2502-826X; e-ISSN: 2503-1163

Copyrights@ Balitar Islamic University, Blitar, Indonesia; Http://jares.unisbablitar.ejournal.web.id

Citation: Supriyono. 2016. Developing Character Education with Reference to

Islamic Perspective: A Conceptual Review. JARES, (2016), 1(1): 1-32.

- Consideration for others

- Compassion

- Kindness

- Obedience [to rightful authority]

- Duty [obligation.]

These eight objective values are the cornerstones of character formation.

In Britain, character education has long been concerned and applied in the context of greek tradition and christian tradition. Only after the 19th century the chracter education was moved to the develoment of character that fitted pupils for their future role in society. Arthur, J., Crick, R.D., Samuel, E., Wilson, K., and McGettrick, B. (2006) said that

"Thus the production of persons suited to the needs of work was the dominant purpose of elementary education. Teachers inculcated social roles by requiring obedience without question and punishing deviant behaviour, and were often poorly educated themselves, having been chosen for."

Whereas, strong characters were required to support the principled stand they would need to take in favour of the established virtues of society, such as bravery, loyalty, diligence, application and manners. Having this contrast, researches on the character education were conducted and suggested that character education shall be designed and conducted with reference to the research results.

To conclude for having discussion on the development of character education in the United States, Indonesia, Australia, New Zealand, and the Great Britain, it is understood that character education does not merely develop good behaviors, but also building norms and values.

\section{THE ISLAMIC PERSPECTIVE OF CHARACTER EDUCATION}

Character Education and focused moral teaching-Tahdhib and Akhlaq-are essential components in teaching the true message of Islam, and linking Iman-faith with amal -action. Belief and ritual worship without moral behavior and good character are worthless. When Rasulullah was asked about religion, he answered that religion is morality.

Acceptance of Islam and being a Muslim carries an obligation to be the best human being one can be by following the example of Prophet Mohammad (S). The character of our beloved Prophet Mohammad (S) was the greatest testimony for the truth of his (S) message. Our conscious effort to teach and exemplify good moral behavior will help us emulate our beloved Prophet Mohammad (S) who stated: "Verily, I have been sent to perfect morals."

Agustian (2005) introduced the Emotional Spiritual Quotient bulding using the socalled 165. 1 (one) means Ikhsan, 6 (six) means Iman, and 5 (five) means Islam. These are basic reference to develop muslim character. By understanding Ikhsan (1), people will purify their heart and soul. Everybody, then, has good values and norms. By understanding Iman 
JARES, Vol. 1 No. 1 March, 2016; p-ISSN: 2502-826X; e-ISSN: 2503-1163

Copyrights@ Balitar Islamic University, Blitar, Indonesia; Http://jares.unisbablitar.ejournal.web.id

Citation: Supriyono. 2016. Developing Character Education with Reference to

Islamic Perspective: A Conceptual Review. JARES, (2016), 1(1): 1-32.

(6), people will have moral princilples on the basis of Rukum Iman. By understanding Islam (5), everyone will have successful steps in taking action on the basis of Rukun Islam.

Agustian, further, introduced the model using the perpective of universal and comprehensive messages of Islam. The ESQ Model makes an awarenerss of core human potential the so called God Spot. The God Spot is the purity of human soul. This is highy relate to the holy spirit, the Almighty God. This is related with Ikhsan. In order to purify heart and soul, human being is asked to do the zero mind process. The zero mind process concerns the positive thinking, positive feeling, and positive behavior. Character development is geared towards the mental building by using the six principles.

These six principles are derived from rukun Iman. The six principles include (1) the star principle which is the way of life, (2) Angel principle to inspire people to trust oneself, (3) Leadership principle to be guide as an influential leader, (4) Learning principle to motivate continuous improvement, (5) Vision principle to be future oriented, and (6) Well-organized principle that develop the mental system within the tauhid. Therefore, character development does not only concern morality, norms, and value, but the comprehensive knowing, undestanding, feeling, and acting with reference the relationship among onself, God The Almighty, and Nature. The star principle is developed in mind, feeling, and action as the comprehensive understanding of the Iman to Allah. Allah The Almighty has guided human being with the book which has no doubt in its content as the guidance of the Mutaqin. Allah reveales:

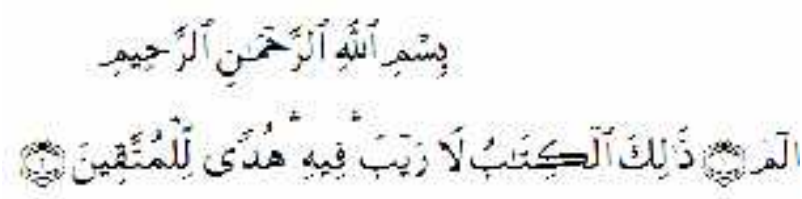

"In the name of Allah, Most Gracious, Most Merciful. This is the Book (Qur'an); In it is guidance sure, without doubt, To those who fear Allah". (QS Al-Baqarah (2):1-2)

The Mutaqin people are those who have good character.

Angle principle is developed on the basis of our comprehension to the believe in the Angles of Allah. Leadership principle is developed on the basis of the comprehension to the believe in Allah's messangers that will enable people to be wise and good leaders. Learning principle is developed on the basis of our comprehension towards the believe in the books of Allah as the human being guidance. Vision principle is developed on the basis of our comprehension to the believe in the day of judgement and therefore, people will be able to identify good or bad, wright or wrong, and to do good deeds. The Well organized principle is developed on the basis of our comprehension to the believe in "qada' and "qadar". Only 
JARES, Vol. 1 No. 1 March, 2016; p-ISSN: 2502-826X; e-ISSN: 2503-1163

Copyrights@ Balitar Islamic University, Blitar, Indonesia; Http://jares.unisbablitar.ejournal.web.id

Citation: Supriyono. 2016. Developing Character Education with Reference to

Islamic Perspective: A Conceptual Review. JARES, (2016), 1(1): 1-32.

Allah knows what Allah decides and what Allah does not decide, therefore we need to keep alirt to be a good creature of Allah by being well-organized.

Furthermore, in terms on good behavioral action, these are combined with the 5 (five) potentials as personal and social strenghts that have been developed on the basis of rukun Iman. The personal strengths consist of (1) Mission statement, (2) character building, and (3) self-control. To have a good character, ones will have to realize who he is. Every human being has been given high potential by Allah and therefore to succeed with good character, ones are oblighted to have mission statement. This is derived from the understanding of Syahadah. Believing that Allah is the only one supreme God and Rasulullah is the messanger of Allah can definitely gear towards the self-awareness, the awareness toward the Great creator, and the awareness towords the intention of Allah to send the Messangers for human being lives. Character education will then be developed by learning the submission to Allah and following the Messangers of Allah.The second strenght, which is, character building is developed from our comprehension of the obligation to do Shalat. Everybody will have a good character when he respect Allah, respect one self, respect the messanger, respect time and rules, and respect other people. There is no one who hate or who are angry with other people when they do shalat. The third strenght is self-control that is developed through the understanding of fasting (Shaum). Whosoever succeeds to do self control, he or shewill likely have a good character.

The two Social Strengths consist of Strategic Collaboration and Total Action. The former is developed through the understanding of Zakat and the later is developed through the understanding of Hajj. How shall the character developed using these two comprehensions? Parts of the answer are when you are able to give others and respect others to work together for the same aims, you actually reveals your good character. To have a close look on the model, the following is the ESQ 165 Ways. 
JARES, Vol. 1 No. 1 March, 2016; p-ISSN: 2502-826X; e-ISSN: 2503-1163

Copyrights@ Balitar Islamic University, Blitar, Indonesia; Http://jares.unisbablitar.ejournal.web.id

Citation: Supriyono. 2016. Developing Character Education with Reference to

Islamic Perspective: A Conceptual Review. JARES, (2016), 1(1): 1-32.

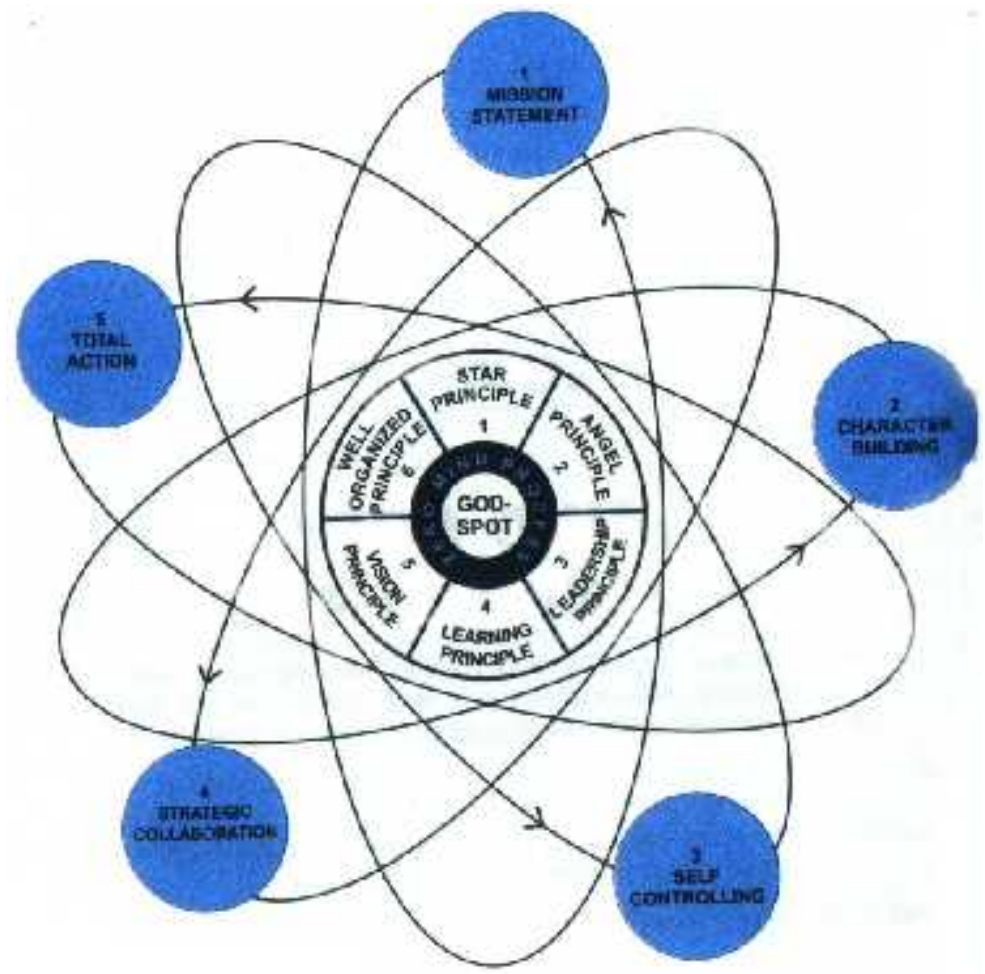

Figure 7: The ESQ Model

Of all above discussion, the important things to consider are using the Qur'an as the guidance for the development of good character since all traits discussed above are just parts of comprhensive good character formulations revealed in the Qur'an and following the Sunnah as all of those above traits of character are just parts of the Rasulullah's traits. As a citizen of Indonesia, Pancasila values will be of good references to develop good character.

\section{PROPOSED WAYS OF DEVELOPING GOOD CHARACTER}

Synthesizing the obove discussion, the writer proposes the following ways of developing good character for our education system.

First, consider that our education is not only as Tarbiya which is developing individual potential and a process of bring up and care children to be mature, but also Ta'dib which is a process of character development and educating moral action, social behavior in the communities, and comprehending of the social principles such as justice, and also Ta'lim which is developing and enhancing knowledge. So, before we consider the character education, we first redefine our education as the combination of Tarbiya, Ta'dib, and Ta'lim. 
JARES, Vol. 1 No. 1 March, 2016; p-ISSN: 2502-826X; e-ISSN: 2503-1163

Copyrights@ Balitar Islamic University, Blitar, Indonesia; Http://jares.unisbablitar.ejournal.web.id

Citation: Supriyono. 2016. Developing Character Education with Reference to

Islamic Perspective: A Conceptual Review. JARES, (2016), 1(1): 1-32.

Antonio (2007:182-183) confirms that education must be defined as a wholistic process. According to him, education in Arabic refers to "ta'lim", "tarbiyah", and "ta'dib", "tadris", "irsyad", and "indzar". Tarbiyah concept is understood as educating people to improve their lives towards ideal situation. Tarbiyya develop people potential in physical potential, spiritual potential, intelectual potential, and material potential. This process is done to understand the happiness of the herenow and hereafter. Ta'lim appears in the Allah's revelation in QS Al-Baqarah (2):31 as follows:

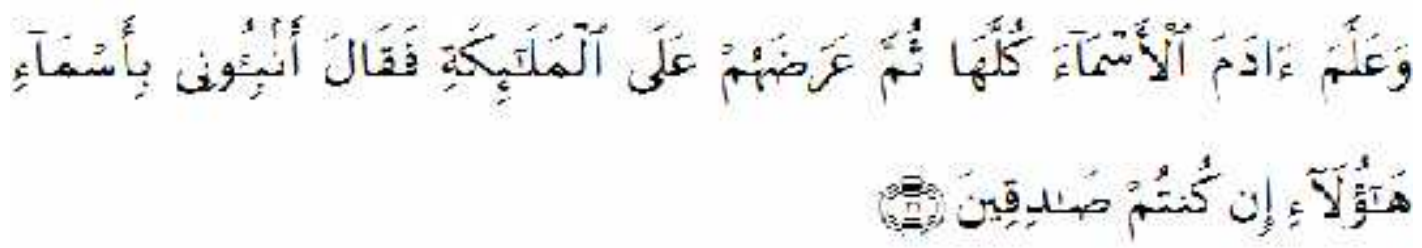

"And He aught Adam the names Of all things; then Heplaced them Before the angles, and said:"'Tell Me The names of these if ye are right."(QS AlBaqarah (2):31)

Whereas, $t a$ 'dib appears in the speech of Rasulullah SAW as the following:

"Allah educates me and therefore He give me the best education" (Cited from Antonio 2007:183. Eventhough, this is considered as the dha' if Hadith).

Second, enable our students and educators to read and think of the relation of human beings, Allah, and Nature. Allah revealed:

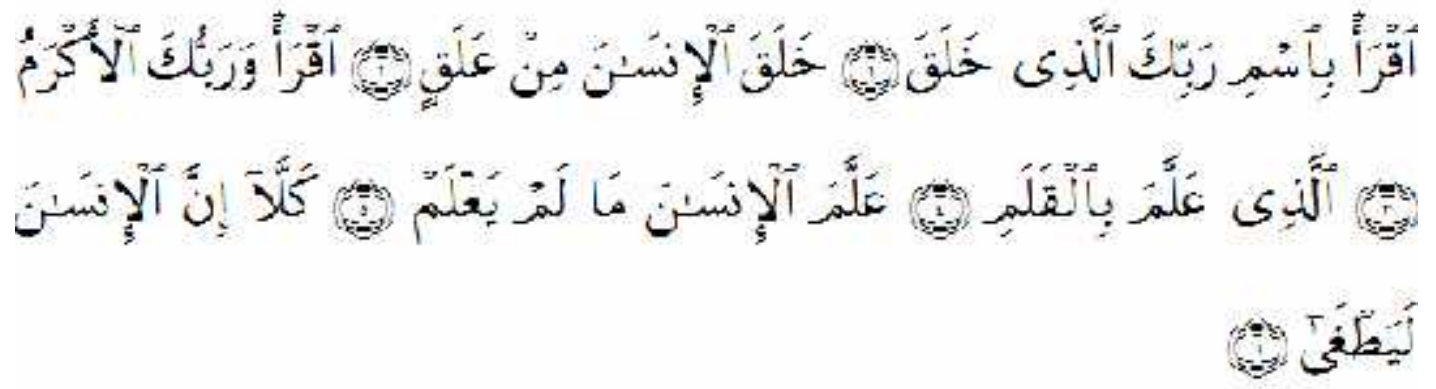

"Proclaim (Read) In the Name of thy Lord and the Cherisher, Who created - Created man, out of A (mere)clot Of thy congealed blood. Proclaim! And thy Lord Is Most Bountiful. He Who taught (The use of) the Pen-Taught the man that which he knew not" (QS Al-Alaq (96):1-5)

Third, geared the educational objectives towards the quality of good heart and soul (Ikhsan), good action of the faithful principles (Iman), and good strategies and ways of social actions (Islam).

Fourth, cover all the wholistic dimension of education that include Physical Quotient and Social Quotient, Intelectual Quotient, Emotional Quotient, and Spiritual Quotient. 
JARES, Vol. 1 No. 1 March, 2016; p-ISSN: 2502-826X; e-ISSN: 2503-1163

Copyrights@ Balitar Islamic University, Blitar, Indonesia; Http://jares.unisbablitar.ejournal.web.id

Citation: Supriyono. 2016. Developing Character Education with Reference to

Islamic Perspective: A Conceptual Review. JARES, (2016), 1(1): 1-32.

Fifth, consider that education is dealing with the golden connection among school, family, and community.

Sixth, have a shared decision to define and develop traits of character especially characterized your education system. The basic four traits of Rasullullah charcter shall be the driving force for other traits. These are Fatonah, Amanah, Sidiq, and Tabliq.

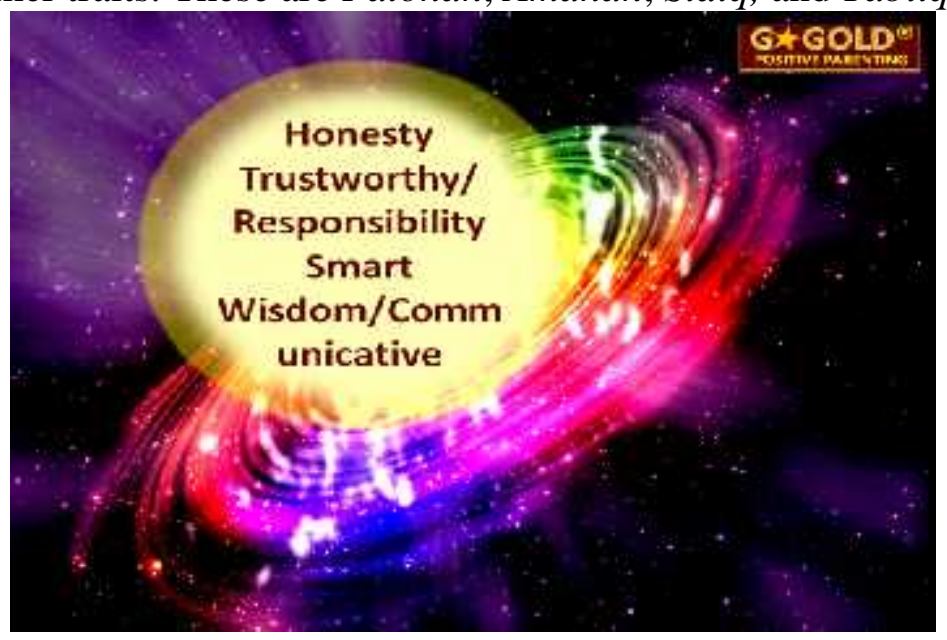

Figure 8: Four Basic Character (Supriyono, 2011)

Seventh, develop the positive attitudes in expectation, thinking, feeling, and doing.

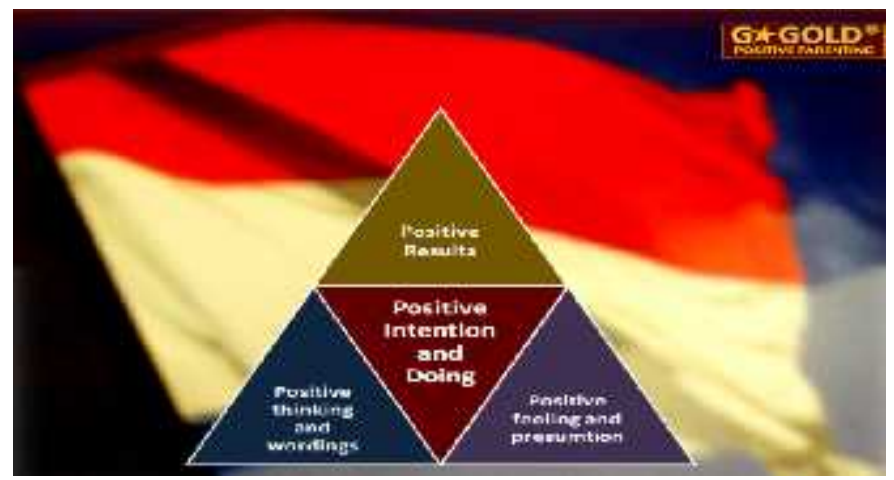

Figure 9: The Positivistic Acts (Supriyono, 2011)

Eight, promotes the G*GOLD approach to developing character, which are Greatness (Every body has great potential and therefore should be respected), Gratitude (All greatnes and potential are the gifth from Allah-Syukur), Obedience (Every body obey the shared rules, regulations, norms, and values), Love (have human relation with caring), and Discipline (Every discipline action will result good outcomes) 
JARES, Vol. 1 No. 1 March, 2016; p-ISSN: 2502-826X; e-ISSN: 2503-1163

Copyrights@ Balitar Islamic University, Blitar, Indonesia; Http://jares.unisbablitar.ejournal.web.id

Citation: Supriyono. 2016. Developing Character Education with Reference to

Islamic Perspective: A Conceptual Review. JARES, (2016), 1(1): 1-32.

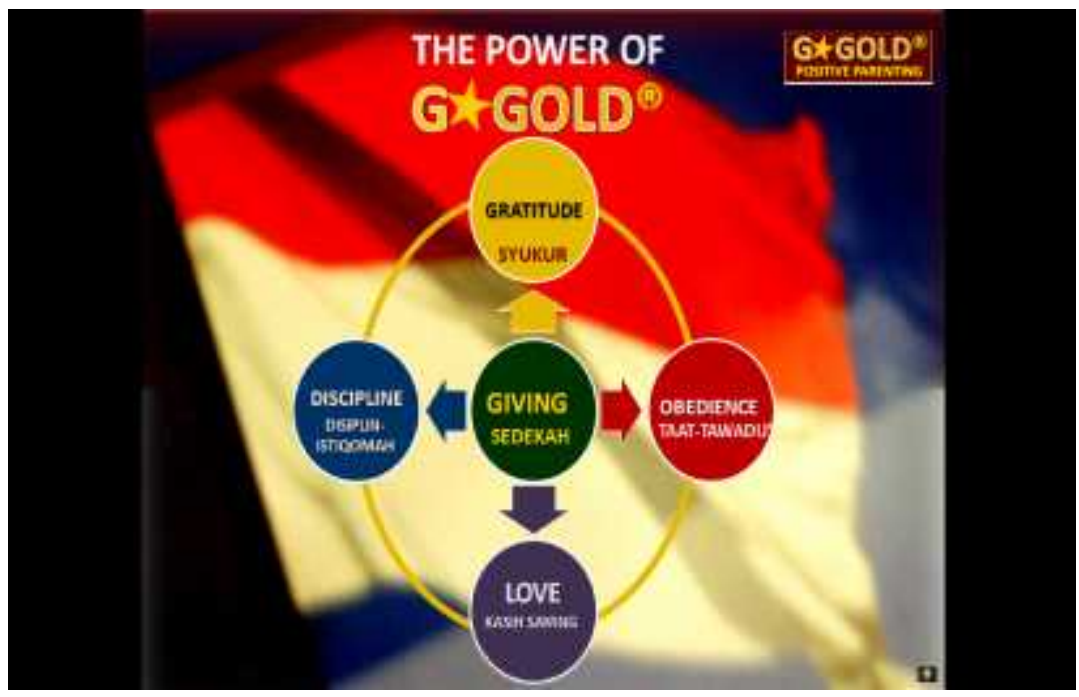

Figure 10: G*GOLD Ways of Character Development (Supriyono, 2012)

Nine, implement the character education strategies within schools, home, and community with giving role model, exemplification, and habituation.

Tenth, make reflective and corrective action for continuous improvement.

\section{G*GOLD PRINCIPLES AND CHARACTERS}

$\mathrm{G}^{*}$ GOLD Way is an approach to positively develop self integrity and quality to succeed doing self management and taking roles in all sorts of life in any profession as well as life activities. G*GOLD Way has a basic philosophy that firstly, everyone has been created by Allah the Almighty with their own characters and potential; secondly there is a harmonious relationship among people or human nature, other world creatures, environment, and the most gretaest creator of the univers (Allah), thirdly, within the body, mine, and soul of everyone there have been goodness wisdom (Ilham kebaikan) and badness traiths (Ilham kefasikan) and therefore purifying the soul is the basic concern of G*GOLD Way; fourthly, the furification of the soul can be simply done by exemplifying the four main characters of Muhammad which are Fatonah, Amanah, Sidig, and Tabligh (FAST) which are in the G*GOLD Way principals called Jujur, Amanah, Cerdas, and Komunikatif as well as Bijaksana (JACK); Fifthly, all people can be positive and so G*GOLD Way believes that thinking, desiring, feeling, saying, and doing positively result positive outcomes, and Sixthly, the approach consists of 5 Plus one Star principls, which Greatness (G), (Star), Gratitude, Obedience, Love, and Discipline (G GOLD).

These principles were designed ons basis of the Qur'anic and Prophetic Values, the Values of EMtional and Spiritual Quotion development, the principle of Law of Attraction and self energy development using Psychotronica method, and theoretical references on the human potential, such as Phisical, Intellectual, Social Emotional, and 
JARES, Vol. 1 No. 1 March, 2016; p-ISSN: 2502-826X; e-ISSN: 2503-1163

Copyrights@ Balitar Islamic University, Blitar, Indonesia; Http://jares.unisbablitar.ejournal.web.id

Citation: Supriyono. 2016. Developing Character Education with Reference to

Islamic Perspective: A Conceptual Review. JARES, (2016), 1(1): 1-32.

Spiritual Quotions, as well as multiple intelligences. The G*GOLD principles will also be compatible with any sorts of study field and profession. G*GOLD Way emerged the philosophy of prayer, positive mind set, action taking, and change for better life in the herenbow and hereafter. The followings are the description of the G*GOLD Principles aor characters.

\begin{tabular}{|c|c|c|c|c|}
\hline No & Core Concept & Basic Principles & Characters & References \\
\hline 1 & $\begin{array}{l}\text { Jujur, Amanah, } \\
\text { Cerdas, } \\
\text { Komunikatif, and } \\
\text { Bijaksana (JACK) }\end{array}$ & $\begin{array}{l}\text { - Allah has install } \\
\text { the goodness } \\
\text { wisdom within } \\
\text { all human mind, } \\
\text { body, and soul, } \\
\text { therefore it is } \\
\text { highly } \\
\text { recommended } \\
\text { for anyone to be } \\
\text { honest, } \\
\text { thrusworthy, } \\
\text { smart, } \\
\text { communicative, } \\
\text { and wise }\end{array}$ & $\begin{array}{l}\text { - Honesty } \\
\text { - Trustworthy } \\
\text { - Creative thinking } \\
\text { - Critical thinking, } \\
\text { - Constructive } \\
\text { thinking, } \\
\text { - Innovative } \\
\text { thinking, } \\
\text { - Communicative } \\
\text { - Wise (Fair, Just, } \\
\text { Good Listener, } \\
\text { and firm) }\end{array}$ & $\begin{array}{ll}\text { - } & \text { Quranic } \\
\text { values } \\
\text { - } & \text { Prophetic } \\
\text { Values } \\
\text { - Studies of } \\
\text { ESQ, } \\
\text { Multiple } \\
\text { Intelligen- } \\
\text { ces, and } \\
\text { profes- } \\
\text { sional } \\
\text { develop- } \\
\text { ment } \\
\text { studies } \\
\text { Life } \\
\text { experience }\end{array}$ \\
\hline 2 & $\begin{array}{l}\text { Triangle of } \\
\text { Positivism } \\
\text { (Thinking, } \\
\text { Perceiving, and } \\
\text { Feeling Positively, } \\
\text { Saying Positively, } \\
\text { Acting positively) }\end{array}$ & $\begin{array}{l}\text { • G*GOLD Way } \\
\text { beleives that } \\
\text { Thinking, } \\
\text { Perceiving, } \\
\text { Feeling, Saying, } \\
\text { and Acting } \\
\text { positively will } \\
\text { result positive } \\
\text { outcomes) } \\
\text { - This triangle of } \\
\text { positivism will } \\
\text { be best done } \\
\text { using the } \\
\text { principle of } \\
\text { JACK } \\
\text { - Thinking, } \\
\text { Perceiving, }\end{array}$ & $\begin{array}{l}\text { - Positive thinking } \\
\text { - Positive } \\
\text { perception } \\
\text { - Positive feeling } \\
\text { - Positive acting } \\
\text { - Confidence }\end{array}$ & $\begin{array}{ll}\text { - Quranic } \\
\text { values } \\
\text { - } \text { Prophetic } \\
\text { Values } \\
\text { - Studies of } \\
\text { ESQ, } \\
\text { Multiple } \\
\text { Intelligenc } \\
\text { es, and } \\
\text { profes- } \\
\text { sional } \\
\text { develop- } \\
\text { ment } \\
\text { studies } \\
\text { - Life } \\
\text { experience }\end{array}$ \\
\hline
\end{tabular}


JARES, Vol. 1 No. 1 March, 2016; p-ISSN: 2502-826X; e-ISSN: 2503-1163

Copyrights@ Balitar Islamic University, Blitar, Indonesia; Http://jares.unisbablitar.ejournal.web.id

Citation: Supriyono. 2016. Developing Character Education with Reference to

Islamic Perspective: A Conceptual Review. JARES, (2016), 1(1): 1-32.

\begin{tabular}{|c|c|c|c|c|}
\hline & & $\begin{array}{l}\text { Feeling, and } \\
\text { Saying equals to } \\
\text { prayers that } \\
\text { Allah requires } \\
\text { human being to } \\
\text { do and equals to } \\
\text { Law of } \\
\text { Attraction that } \\
\text { Allah has } \\
\text { promised to } \\
\text { make what we } \\
\text { pray with } \\
\text { confidence } \\
\text { happens (See } \\
\text { Adzariat } 23 \text { ) } \\
\text { - Acting } \\
\text { positively } \\
\text { equals to } \\
\text { working and } \\
\text { changing for } \\
\text { better life which } \\
\text { Allah has } \\
\text { promised that } \\
\text { every nation } \\
\text { that eagerly } \\
\text { change } \\
\text { themselves will } \\
\text { be changed } \\
\text { positively. }\end{array}$ & & \\
\hline 3 & $\begin{array}{l}\text { GఓGOLD } \\
\text { 1. Greatness }\end{array}$ & $\begin{array}{l}\text { - Every human } \\
\text { being is great } \\
\text { - Every human } \\
\text { being is created } \\
\text { to be the leaders } \\
\text { on earth } \\
\text { (Khalifah) with } \\
\text { all their potential } \\
\text { such as Mind } \\
\text { (Akal or Al } \\
\text { Aqlu), Body }\end{array}$ & $\begin{array}{l}\text { - Self awareness } \\
\text { - Self reliance } \\
\text { - Motivated } \\
\text { - Initiative } \\
\text { - Self professional } \\
\text { development } \\
\text { - Confidence } \\
\text { - Self Control } \\
\text { - Intrapersonal } \\
\text { development } \\
\text { - Contributive }\end{array}$ & $\begin{array}{ll}\text { - } & \text { Prophetic } \\
\text { Values } \\
\text { - } & \text { Studies of } \\
\text { ESQ, } \\
\text { Multiple } \\
\text { Intelligenc } \\
\text { es, and } \\
\text { profes- } \\
\text { sional } \\
\text { develop- } \\
\text { ment }\end{array}$ \\
\hline
\end{tabular}


JARES, Vol. 1 No. 1 March, 2016; p-ISSN: 2502-826X; e-ISSN: 2503-1163

Copyrights@ Balitar Islamic University, Blitar, Indonesia; Http://jares.unisbablitar.ejournal.web.id

Citation: Supriyono. 2016. Developing Character Education with Reference to

Islamic Perspective: A Conceptual Review. JARES, (2016), 1(1): 1-32.

\begin{tabular}{|c|c|c|c|}
\hline & $\begin{array}{l}\text { (Raga or } \\
\text { Jasmani), } \\
\text { Thinking (Rasio } \\
\text { or Pemikiran), } \\
\text { Heart (Al Qalbu } \\
\text { or Hati), Soul } \\
\text { (Jiwa or Ruh), } \\
\text { and Desire } \\
\text { (Nafsu) and } \\
\text { therefore every } \\
\text { human being has } \\
\text { great potentials }\end{array}$ & $\begin{array}{l}\text { - Solutive } \\
\text { - Problem Solver } \\
\text { - Inovative } \\
\text { - Creative } \\
\text { - Interpersonal } \\
\text { development } \\
\text { - Self management } \\
\text { - Unleasing } \\
\text { potential as } \\
\text { Intellectual, } \\
\text { Socio emotional, } \\
\text { Phisical, and } \\
\text { Spiritual } \\
\text { Quotion, } \\
\text { - Unleasing } \\
\text { potential as the } \\
\text { multipple } \\
\text { intelligence }\end{array}$ & $\begin{array}{l}\text { studies } \\
\text { - Life } \\
\text { experience }\end{array}$ \\
\hline 2. Gratitude & $\begin{array}{l}\text { - Every human } \\
\text { being is created } \\
\text { as the khalifa } \\
\text { of the earth and } \\
\text { created in } \\
\text { different tribes, } \\
\text { languages, as } \\
\text { well as cultures } \\
\text { in order to } \\
\text { acknowldge } \\
\text { one among } \\
\text { others (AL } \\
\text { Hujarat 13) } \\
\text { Every human } \\
\text { being lives } \\
\text { socially and } \\
\text { therefore they } \\
\text { have to respect } \\
\text { other people }\end{array}$ & $\begin{array}{l}\text { - Wise (Thankful } \\
\text { to Allah the } \\
\text { Almighty) } \\
\text { - Respectful and } \\
\text { appreciative } \\
\text { - Keen to help } \\
\text { and to get help } \\
\text { - Collaborative } \\
\text { - Communicative } \\
\text { - Eager to work } \\
\text { in team and } \\
\text { network } \\
\text { - Eager to share } \\
\text { ideas } \\
\text { - Eager to listen } \\
\text { others } \\
\text { - Collegial self } \\
\text { and } \\
\text { professional } \\
\text { development } \\
\text { - Collegially } \\
\text { solutive }\end{array}$ & $\begin{array}{ll}\text { - } & \text { Prophetic } \\
\text { Values } \\
\text { - Studies of } \\
\text { ESQ, } \\
\text { Multiple } \\
\text { Intelligenc } \\
\text { es, and } \\
\text { profes- } \\
\text { sional } \\
\text { develop- } \\
\text { ment } \\
\text { studies } \\
\text { - Life } \\
\text { experience }\end{array}$ \\
\hline
\end{tabular}


JARES, Vol. 1 No. 1 March, 2016; p-ISSN: 2502-826X; e-ISSN: 2503-1163

Copyrights@ Balitar Islamic University, Blitar, Indonesia; Http://jares.unisbablitar.ejournal.web.id

Citation: Supriyono. 2016. Developing Character Education with Reference to

Islamic Perspective: A Conceptual Review. JARES, (2016), 1(1): 1-32.

\begin{tabular}{|c|c|c|c|}
\hline 3. Obedience & $\begin{array}{l}\text { Every human } \\
\text { being has } \\
\text { tightly related } \\
\text { to Allah the } \\
\text { Almighty and } \\
\text { to community } \\
\text { as habits, } \\
\text { culture, and } \\
\text { social norms } \\
\text { and therefore } \\
\text { being } \\
\text { obedience will } \\
\text { make the world } \\
\text { peaceful and } \\
\text { life heppier. }\end{array}$ & $\begin{array}{l}\text { - } \begin{array}{l}\text { Committed } \\
\text { (Commitment) }\end{array} \\
\text { - Contributive to } \\
\text { norms and } \\
\text { values } \\
\text { development } \\
\text { - Consistent, } \\
\text { - Follow the } \\
\text { rules, norms, } \\
\text { and values, } \\
\text { - Apologetic, but } \\
\text { firm in decition } \\
\text { - Intolerrance to } \\
\text { breaking rules, } \\
\text { norms, values, } \\
\text { and } \\
\text { commitment }\end{array}$ & $\begin{array}{ll}\text { - } & \text { Prophetic } \\
\text { Values } \\
\text { - Studies of } \\
\text { ESQ, } \\
\text { Multiple } \\
\text { Intelligenc } \\
\text { es, and } \\
\text { profes- } \\
\text { sional } \\
\text { develop- } \\
\text { ment } \\
\text { studies } \\
\text { - Life } \\
\text { experience }\end{array}$ \\
\hline 4. Love & $\begin{array}{l}\text { Every human } \\
\text { being has good } \\
\text { soul and heart, } \\
\text { so Loving } \\
\text { nature, loving } \\
\text { people, and } \\
\text { loving the } \\
\text { society in } \\
\text { terms of } \\
\text { valuing nature } \\
\text { and human } \\
\text { beings as the } \\
\text { exempification } \\
\text { of Rahman dan } \\
\text { Rahim will } \\
\text { create our life } \\
\text { better }\end{array}$ & $\begin{array}{l}\text { - } \text { Caring } \\
\text { - Helpful } \\
\text { - Positive } \\
\text { thinking } \\
\text { - Positive } \\
\text { attitude } \\
\text { - Positive } \\
\text { behavior } \\
\text { - Solutive } \\
\text { - Motivative }\end{array}$ & $\begin{array}{ll}\text { - } & \text { Prophetic } \\
\text { - } & \text { Salues } \\
\text { ESudies of } \\
\text { Multiple } \\
\text { Intelligenc } \\
\text { es, and } \\
\text { profes- } \\
\text { sional } \\
\text { develop- } \\
\text { ment } \\
\text { studies } \\
\text { - Life } \\
\text { experience }\end{array}$ \\
\hline 5. Discipline & $\begin{array}{l}\text { Of the flowing } \\
\text { time, every } \\
\text { human being is } \\
\text { basically will } \\
\text { disadvantaged, } \\
\text { therefore, } \\
\text { discipline is the }\end{array}$ & $\begin{array}{l}\text { - Discipline } \\
\text { - Consistent } \\
\text { - Timely } \\
\text { managed } \\
\text { - Trustworthy } \\
\text { - Dilligent }\end{array}$ & $\begin{array}{ll}\text { - } & \text { Prophetic } \\
& \text { Values } \\
\text { - } & \text { Studies of } \\
\text { ESQ, } \\
\text { Multiple } \\
\text { Intelligenc } \\
\text { es, and }\end{array}$ \\
\hline
\end{tabular}


JARES, Vol. 1 No. 1 March, 2016; p-ISSN: 2502-826X; e-ISSN: 2503-1163

Copyrights@ Balitar Islamic University, Blitar, Indonesia; Http://jares.unisbablitar.ejournal.web.id

Citation: Supriyono. 2016. Developing Character Education with Reference to

Islamic Perspective: A Conceptual Review. JARES, (2016), 1(1): 1-32.

\begin{tabular}{|c|c|c|c|c|}
\hline & & $\begin{array}{l}\text { best way to } \\
\text { experience life. }\end{array}$ & $\begin{array}{l}\text { - Supportive } \\
\text { - Motivative }\end{array}$ & $\begin{array}{l}\text { profes- } \\
\text { sional } \\
\text { develop- } \\
\text { ment } \\
\text { studies } \\
\text { - } \\
\text { Life } \\
\text { experience }\end{array}$ \\
\hline & 6 Star $(\vec{s})$ & $\begin{array}{l}\text { Win the change } \\
\text { and share the } \\
\text { glory } \\
\text { - Star principles } \\
\text { (Using Quranic } \\
\text { and Prophetic } \\
\text { Values as } \\
\text { much as we } \\
\text { can, we will be } \\
\text { successful) }\end{array}$ & $\begin{array}{l}\text { - Winner Mind } \\
\text { Set } \\
\text { - Universal } \\
\text { Glory mind set } \\
\text { - Winning means } \\
\text { the success of } \\
\text { those who } \\
\text { support the } \\
\text { winners }\end{array}$ & $\begin{array}{ll}\text { - } & \text { Prophetic } \\
\text { Values } \\
\text { - Studies of } \\
\text { ESQ, } \\
\text { Multiple } \\
\text { Intelligenc } \\
\text { es, and } \\
\text { profes- } \\
\text { sional } \\
\text { develop- } \\
\text { ment } \\
\text { studies } \\
\text { - Life } \\
\text { experience }\end{array}$ \\
\hline 4 & $\begin{array}{l}\text { Triangle of Success } \\
\text { (Scientific or } \\
\text { Ilmiah, Naturalistic } \\
\text { or Alamiah, and } \\
\text { Prophetic or } \\
\text { Illahiah) }\end{array}$ & $\begin{array}{l}\text { - Allah has given } \\
\text { us the potential } \\
\text { to think and } \\
\text { work } \\
\text { (Afalayatafakar } \\
\text { un) so doing } \\
\text { our tasks } \\
\text { scientifically } \\
\text { will result } \\
\text { positive } \\
\text { outcomes, } \\
\text { Allah has given } \\
\text { us multiple } \\
\text { intelligences, } \\
\text { so that using } \\
\text { our } \\
\text { intelligences in } \\
\text { doing our taks } \\
\text { naturally will } \\
\text { contribute }\end{array}$ & $\begin{array}{l}\text { - Scientific } \\
\text { - Naturalistic } \\
\text { - Prophetic }\end{array}$ & $\begin{array}{ll}\text { - } & \text { Prophetic } \\
\text { - } & \text { Salues } \\
\text { Etudies of } & \text { ESQ, } \\
\text { Multiple } \\
\text { Intelligenc } \\
\text { es, and } \\
\text { profes- } \\
\text { sional } \\
\text { develop- } \\
\text { ment } \\
\text { studies } \\
\text { - Life } \\
\text { experience } \\
\text { - }\end{array}$ \\
\hline
\end{tabular}


JARES, Vol. 1 No. 1 March, 2016; p-ISSN: 2502-826X; e-ISSN: 2503-1163

Copyrights@ Balitar Islamic University, Blitar, Indonesia; Http://jares.unisbablitar.ejournal.web.id

Citation: Supriyono. 2016. Developing Character Education with Reference to

Islamic Perspective: A Conceptual Review. JARES, (2016), 1(1): 1-32.

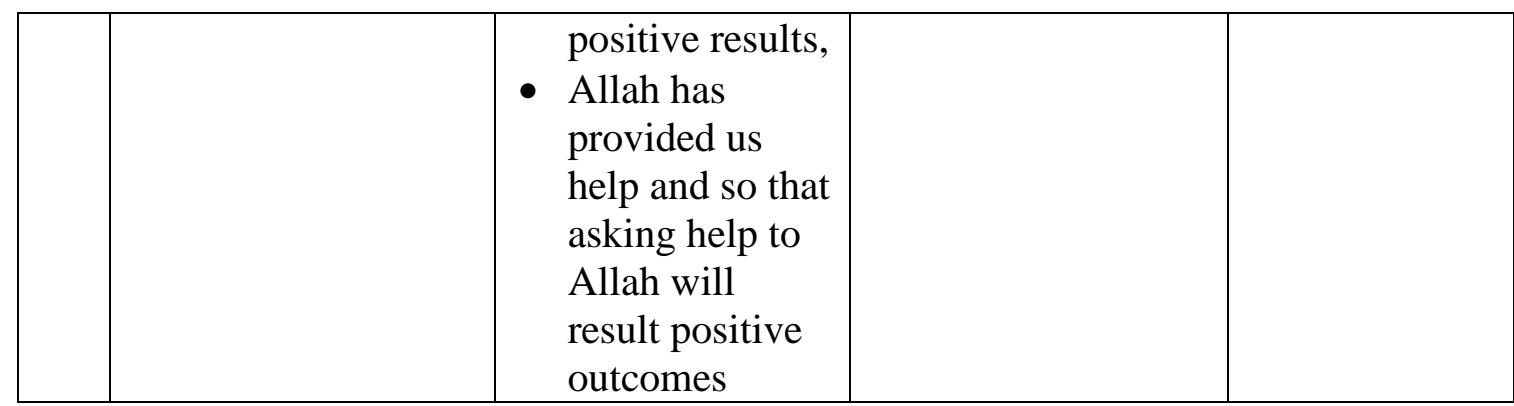

These all characters immerged in the $\mathrm{G}^{*} \mathrm{GOLD}$ Way philosphy and principles that can be adopted creatively in any sorts of life. When these are trained and educated to children and parents, these are trained and educated using simple and interesting ways by using the references of ESQ Way, Psychotronica, Suggestopedia, and Interactive methods.

\section{CONCLUSION}

Character education is indeed very important to consider for developing good citizen both for the development and building of morality, norms, and values for better lives. It has been concerns of many countries in the world including Indonesia, the United States of America, Great Britain, Australia, and New Zealand.

Character education is done through academic lessons, habituations, creativity-actionand services. It is suggested that character development is internalized in the wholistic education system by developing the whole students' potential through various active learnings and habituation.

Since character education in Indonesia has been the priority and the implentation is mandated to be involved in all subject matters through curriculair activities and extracurriculair activities, effective practical implementation shall be taken care off. The basic things to develop would be the strenghtenning of being valued people as in ikhsan, being good creatures of Allah as in Iman, and being able to do good deeds and moral action in the community as in Islam.

\section{REFERENCE}

Al Qur'an

Australian Government, Department of Education, Science, and Training. 2005.

National Framework for Values Educationin Australian Schools. Canbera: Australian Government, Department of Education, Science, and Training

Agustian, A.G.2005.The Islamic Guide to Developing ESQ Applying The Way 165. Jakarta: Arga Publishing

Ali, A.Y.1989.The Meaning of The Holy Qur'an.Maryland:Amana Corporation 
JARES, Vol. 1 No. 1 March, 2016; p-ISSN: 2502-826X; e-ISSN: 2503-1163

Copyrights@ Balitar Islamic University, Blitar, Indonesia; Http://jares.unisbablitar.ejournal.web.id

Citation: Supriyono. 2016. Developing Character Education with Reference to

Islamic Perspective: A Conceptual Review. JARES, (2016), 1(1): 1-32.

Bajovic, M., Rizzo, K., and Engemann, J.2009.Character Education Re-Conceptualized For Practical Implementation. Canadian Journal of Educational Administration and Policy, Issue \#92, March 14, 2009. () by CJEAP and the author(s).

Cunningham, C.A.2007. Character Education in Public Schools:The Quest for a Suitable Ontology.USA: National-Louis University

Davidson, M., Lickona, T., and Khmelkov, V.2007.Smart \& Good Schools: A New Paradigm for High School Character Education. WWW2. Cortland. edu/Asset/255920.pdf Downloaded on September 11, 2012

Direktorat Pembinaan Pendidikan Anak Usia Dini.2012.Petunjuk Teknis Penyelenggaraan Pendidikan Karakter Anak Usia Dini.Jakarta:Direktorat Pembinaan Pendidikan Anak Usia Dini

Gholar, C. 2004. Character Education: Creating a Framework for Excellence. Urban Programs Resource Network, Retrieved from Error! Hyperlink reference not valid.. on September 11, 2012

Hadhiri, C.,SP.1993.Klasifikasi Kandungan Al-Qur'an.Jakarta:Gema Insani Press

Huitt, W.G.,Ph.D.2000.Moral and Character Education.Presentation.Valdosta: Valdosta State University

Kementrian Pendidikan Nasional.2011.Pedoman Pelaksanaan Pendidikan Karakter. Jakarta: Kementrian Pendidikan Nasional

Kementrian Pendidikan Nasional.2010.Buku Induk Pembangunan Karakter. Jakarta: Kementrian Pendidikan Nasional

Lickona, T.1993.The Return of Character Education. Educational Leadership. 51. 6-11

Lickona, T., Ed.D., Scaps, E., Ph.D, and Lewis, C.,Ph.D.2007. CEP's Eleven Principals of Effective Character Education. Washington, DC: CEP Character Education Partnership

McClellan, B. E. 1999. Moral education in America: School and the shaping of character from colonial times to the present. New York, NY: Teachers College Press

Nelson, T., Nelson, M.D. and Christoper, J.C.2003. Culture and Character Education: Problem of Interpretation in a Multicultural Society. Journal of Theoretical and Psychological Psy, Vol 23., No 2., 2003.

New Zealand Foundation for Character Education Inc, .2009. The Cornerstone Values Approach to Character Education in New Zealand Schools .NZ: New Zealand Foundation for Character Education Inc.

Salahuddin, P.Z. 2011. CHARACTER EDUCATION IN A MUSLIM SCHOOL: A CASE STUDY OF A COMPREHENSIVE MUSLIM SCHOOL'S CURRICULA. Dissertation. Miami, Florida: FLORIDA INTERNATIONAL UNIVERSITY

Supriyono.2010.Pendidikan Dalam Islam.Ceramah Ramadhan. 4 September 2010. Masdjid Baiturahman Kuala Kencana. Kuala Kencana:Himpunan Masyarakat Muslim Freport Indonesia 
JARES, Vol. 1 No. 1 March, 2016; p-ISSN: 2502-826X; e-ISSN: 2503-1163

Copyrights@ Balitar Islamic University, Blitar, Indonesia; Http://jares.unisbablitar.ejournal.web.id

Citation: Supriyono. 2016. Developing Character Education with Reference to

Islamic Perspective: A Conceptual Review. JARES, (2016), 1(1): 1-32.

Supriyono.2011.The $G^{*} G O L D$ Ways of Positive Parenting.Blitar:Indonesia Bright Supriyono.2012. The Role of Scholars In Realizing The Creative And Professional Nation Generation: An Educational Perspective. White Paper Presented in the International Seminar held by Sekolah Tinggi Ilmu Agama Islam

Diponegoro Tulungagung, East Java, Indonesia On May 26th, 2012

UNDP.2012.Human Development Report.New York:UNDP

Vessels, G., \& Huitt, W. (2005). Moral and character development. Presented at the National Youth at Risk Conference, Savannah, GA, March 8-10.

Retrieved September 11, 2012, from http://chiron.valdosta.

edu/whuitt/brilstar/chapters/ chardev.doc

Whitley, J.G,.2007. Reversing the Perceived Moral Decline in American Schools:

A Critical Literature Review of America's Attempt at Character Education.

VA: The College of William and Mary Williamsburg. 